Dzieje Najnowsze, Rocznik LIII - 2021, 3

PL ISSN 0419-8824

Sławomir Poleszak

https://orcid.org/0000-0003-3857-9938

Oddziałowe Biuro Badań Historycznych

Instytutu Pamięci Narodowej w Lublinie

\title{
Ośmiu ostatnich. Członkowie podziemia antykomunistycznego nieujawnieni podczas amnestii z 1956 r.
}

\begin{abstract}
Abstrakt: W artykule przedstawiono losy ośmiu osób, które nie skorzystały z amnestii w kwietniu 1956 r. i nadal ukrywały się z bronią w ręku przed komunistycznym aparatem represji. Wszyscy oni byli członkami polskiego podziemia niepodległościowego, działając w jego szeregach już w czasie okupacji niemieckiej. Lektura tekstu pozwala poznać charakter ich działalności po kwietniu 1956 r. i odpowiedzieć na pytanie, czy miała ona charakter antykomunistyczny, czy raczej „przetrwania”.
\end{abstract}

Słowa kluczowe: polskie podziemie niepodległościowe, podziemie antykomunistyczne, podziemie zbrojne, żołnierze wyklęci, żołnierze niezłomni, ostatni zbrojni, stalinizm, amnestia $1956 \mathrm{r}$.

Abstract: The article presents the fate of eight people who did not take advantage of the amnesty in April 1956 and continued to hide with arms in hand from the communist repressive apparatus. All of them were members of the Polish independence underground, acting in its ranks already during the German occupation. Reading the text allows one to get to know the nature of their activity after April 1956 and to answer the question whether it was of anti-communist or rather 'survival' character.

Key w ords: Polish independence underground, anti-communist underground, armed underground, cursed soldiers, unbroken soldiers, last armed, Stalinism, amnesty 1956. 
W połowie lat pięćdziesiątych XX w. podziemie niepodległościowe, które 10 lat wcześniej podjęło walkę z siła narzuconym ustrojem komunistycznym i było dla niego pierwszym przeciwnikiem na drodze do władzy, nie istniało już w żadnej zorganizowanej formie. Na początku 1956 r. ukrywały się jeszcze dwie trzyosobowe grupy przetrwania oraz kilkadziesiąt osób, które robiły to indywidualnie. Tkwiąc w ukryciu, mieli poczucie, że znaleźli się w sytuacji bez wyjścia. Część z nich nie skorzystała z ogólnopolskich amnestii, ogłaszanych kolejno w sierpniu 1945 r., lutym 1947 r. czy listopadzie 1952 r. Czynili tak m.in. dlatego, że nie ufali w szczerość i prawdziwość intencji władzy komunistycznej, co potwierdzały liczne tragiczne losy ludzi podziemia, którzy skorzystali z możliwości ujawnienia. Byli też tacy, którzy ujawnili się (najczęściej w 1947 r.), a działania Urzędu Bezpieczeństwa (UB) czy Milicji Obywatelskiej (MO) zmusiły ich do ponownego wejścia w konspirację. Tkwiąc w owej beznadziejnej sytuacji, stali się obiektem działań operacyjnych prowadzonych przez funkcjonariuszy UB, a następnie Służby Bezpieczeństwa (SB). Ich finałem były kolejne aresztowania lub śmierć osaczonych partyzantów. Procesy sądowe ujętych ludzi podziemia stanowiły świetna okazję dla propagandy komunistycznej. Relacjonując ich przebieg, starała się ona przedstawić sądzonych jako pospolitych przestępców, bandytów i degeneratów, którzy nie potrafili zaadaptować się w nowej rzeczywistości. Przy okazji utrwalając czarną legendę całego powojennego podziemia.

Adekwatną ilustrację tego typu działań stanowią losy Józefa Cieśli „Topora” czy Stefana Kobosa „Wrzosa”. Pierwszy z nich swoja konspiracyjną działalność związał z terenem Pogórza Strzyżowskiego, drugi zaś z pograniczem powiatów lubaczowskiego i tomaszowskiego. Kobos konspiracyjną przysięgę złożył 15 XII 1939 r. Początkowo działał w szeregach Organizacji Wojskowej „Longinusa”. W marcu 1940 r., gdy doszło do rozłamu, pozostał w organizacji, która funkcjonowała pod nową nazwa: Konsolidacja Obrony Narodowej „Klon”. Po jej rozbiciu przez Niemców w marcu 1942 r. znalazł się w szeregach Armii Krajowej (AK), gdzie dowodził 3 plutonem 1 kompanii „Narol”, wchodzacej w skład V Rejonu Obwodu AK Tomaszów Lubelski . Z kolei Cieśla przysięgę w Związku Walki Zbrojnej (ZWZ) złożył w 1940 r., obierajac sobie ps. Sokół. Jesienia 1942 r. samowolnie opuścił szeregi AK i przeszedł do Batalionów Chłopskich (BCh). W późniejszym okresie jako „Topór” dowodził dwudziestokilkuosobowym oddziałem partyzanckim. Po zakończeniu wojny obaj aktywnie uczestniczyli w działalności antykomunistycznej². „Topór”, po wyleczeniu ciężkiej rany odniesionej w sierpniu 1945 r., zaopatrzony w fałszywe dokumenty

\footnotetext{
${ }^{1}$ W. Hanus, Jeden z ostatnich. Stefan Kobos „Wrzos” (1900-1976). Przyczynek do dziejów konspiracji na Narolszczyźnie, Rzeszów 2019, s. 29-34, 37-38; por. J. Wołoszyn, Stefan Kobos „Michorowski”, „Wrzos”, w: Ostatni komendanci. Ostatni żotnierze 1951-1963, red. M. Biernat i in., Warszawa 2016, s. 77.

${ }^{2}$ W. Syrek, Józef Cieśla „Topór”. Przeciw brunatnemu i czerwonemu zniewoleniu, Krosno 2009, s. 61 i n.; A. Szycht, Józef Cieśla „Topór”, w: Ostatni komendanci..., s. 91-96.
} 
próbował się zalegalizować. Podejmował pracę zarobkową w różnych miejscach w kraju ${ }^{3}$. Podporucznik „Wrzos” walczył w szeregach Delegatury Sił Zbrojnych na Kraj (DSZ) i Zrzeszenia Wolność i Niezawisłość (WiN), m.in. brał udział w akcji uwolnienia dwóch uwięzionych w Powiatowym Urzędzie Bezpieczeństwa Publicznego (PUBP) w Lubaczowie (marzec 1945 r.) oraz rozbiciu PUBP w Tomaszowie Lubelskim (listopad 1945 r.), skąd zwolniono 50 więzionych tam działaczy niepodległościowych ${ }^{4}$. Obaj nie ujawnili się $\mathrm{w}$ trakcie amnestii z wiosny $1947 \mathrm{r}$. Cieśla posługując się sfałszowanymi dokumentami, próbował w miarę normalnie żyć. Natomiast „Wrzos” kontynuował walkę, stając na czele Samodzielnego Obwodu WiN Tomaszów Lubelski, który liczył ok. stu członków. W jego ramach do początku $1951 \mathrm{r}$. aktywną walkę zbrojna prowadził oddział chor. Jana Leonowicza „Burty”. Od poczatku lat pięćdziesiątych XX w., czyli po rozbiciu siatki obwodu, por. „Wrzos” ukrywał się samotnie, nie podejmując już żadnej działalności. Schronienia użyczali mu zaufani gospodarze, a zapewne nie bez znaczenia pozostawał fakt, że w końcowym okresie okupacji niemieckiej dowodził on obroną mająca na celu niedopuszczenie do ataków nacjonalistycznej partyzantki ukraińskiej na tamtejsze polskie wioski ${ }^{5}$.

Zupełnie inaczej potoczyły się losy Józefa Cieśli. Działania prowadzone przez funkcjonariuszy UB wobec dawnych jego współtowarzyszy sprawiły, że obawiając się ustalenia jego miejsca pobytu, opuścił Śląsk i wrócił na Rzeszowszczyznę. Schronienia i oparcia zaczął szukać na obszarze niedawnej działalności podziemnej. Natomiast zajście z milicją w październiku 1949 r., w którym brało udział kilku późniejszych członków jego oddziału, doprowadziło do tego, że pod koniec 1949 r. utworzono kilkuosobowa grupę zbrojna, która przez kolejne sześć lat prowadziła działalność antykomunistyczna i miała charakter przetrwaniowy ${ }^{6}$. Konieczność zapewnienia sobie środków materialnych potrzebnych do przeżycia wymuszała przeprowadzanie tzw. akcji zaopatrzeniowych. Ponadto gromadzono wszelkie zdatne do użycia jednostki broni (włącznie z myśliwska). W listopadzie 1954 r. dowódca grupy zastrzelił osobę obwiniana o wydanie kryjówki swojego współtowarzysza. Zdaniem funkcjonariuszy UB czyn ten skutecznie odstręczał ludzi od podejmowania współpracy, czym utrudniał działania operacyjne?

Aby go pochwycić, funkcjonariusze UB zastosowali prowokację. W lutym 1955 r. aresztowano jego brzemienną żonę Helenę Piękoś, która następnie w maju 1955 r. zwolniono. W tym czasie w domu jej rodziców w Chrząstówce, w powiecie krośnieńskim, gdzie mieszkała, pracownicy

\footnotetext{
${ }^{3}$ W. Syrek, op. cit., s. 61-65; A. Szycht, Józef Cieśla „Topór”..., s. 97-99.

${ }^{4}$ W. Hanus, op. cit., s. 103 i n.; J. Wołoszyn, op. cit., s. 78.

${ }^{5}$ W. Hanus, op. cit., s. 124 i n., 130 i n.; J. Wołoszyn, op. cit., s. 79, 84.

${ }^{6}$ W. Syrek, op. cit., s. 75-76.

${ }^{7}$ Ibidem, s. 160-161.
} 
operacyjni UB zamontowali aparaturę podsłuchowa. Przez następne kilka miesięcy $\mathrm{w}$ sasiednich zabudowaniach trzech pracowników UB prowadziło nieprzerwany nasłuch. „Topór” pojawił się w domu swoich teściów 30 IX 1955 r., gdyż chciał odwiedzić żonę i zobaczyć swoją niedawno narodzona córeczkę. Zbyt długi jego pobyt umożliwił dotarcie tam grupy operacyjnej złożonej z 4 funkcjonariuszy UB i 30 żołnierzy Korpusu Bezpieczeństwa Wewnętrznego (KBW). W czasie próby ucieczki został raniony i pojmany ${ }^{8}$.

Przez długi okres nieuchwytny pozostawał również Stefan Kobos. Dopiero w listopadzie 1955 r. UB zdołał pozyskać TW „Szczerego”, bliskiego członka jego rodziny, który dostarczył informacji o miejscu ukrycia por. „Wrzosa”. 21 I 1956 r. grupa operacyjna UB-MO-KBW otoczyła wieś Brzeziny k. Narola w powiecie lubaczowskim i zaskoczyła go w kryjówce w stajni Edmunda Szczepańskiego. Odmawiał składania jakichkolwiek wyjaśnień, więc aby zmusić go do zmiany decyzji, zatrzymano jego żonę Marię. Po trzech miesiącach śledztwo w jej sprawie umorzono ${ }^{9}$.

Proces Józefa Cieśli toczył się przed Sądem Wojewódzkim w Rzeszowie. Był on szeroko relacjonowany przez „Nowiny Rzeszowskie”, organ prasowy Komitetu Wojewódzkiego (KW) PZPR. W zamieszczanych tam artykułach określano Cieślę mianem „bandyty”, „jednostki zdeprawowanej i antyspołecznej”, „mordercy” czy „mikołajczykowskiego pachołka”. Sala sądowa była szczelnie wypełniona publicznością. 23 IV $1956 \mathrm{r}$. zapadł wyrok skazujący go na siedmiokrotną karę śmierci, pozbawienie praw publicznych na zawsze i przepadek mienia. Sąd Najwyższy zmniejszył wyrok do 15 lat więzienia. W areszcie znalazła się również jego żona, a władze komunistyczne wykorzystując tę sytuację, podjęły działania majace na celu umieszczenie ich dzieci w domu dziecka. Nie doszło do tego tylko na skutek stanowczego sprzeciwu matki Heleny, Władysławy Piękoś. Aby ustabilizować status żony i dzieci, 1 VI 1956 r. zawarli ślub cywilny (w grudniu 1952 r. - ślub kościelny). Józef Cieśla zmarł 14 XI 1969 r. w więzieniu w Barczewie ${ }^{10}$.

Proces Stefana Kobosa toczył się przed Sądem Wojewódzkim w Lublinie na sesji wyjazdowej w Zamościu i trwał z przerwami od 10 VII do 28 IX 1956 r. Ostatniego dnia zapadł wyrok skazujacy go na karę dożywotniego więzienia. Jednak na podstawie wcześniejszych amnestii zmniejszono ja do 15 lat. Warto wspomnieć, że ludność z Brzezin i wiosek położonych wokół nich napisała petycję w obronie Kobosa. Zaadresowano ją do ówczesnego I sekretarza Komitetu Centralnego (KC) PZPR Edwarda Ochaba. W 1962 r. z powodu ciężkiej choroby serca udzielono mu przerwy w odbywaniu kary. Do więzienia już nie wrócił. Zmarł 24 VII 1976 r. w Opolu ${ }^{11}$.

\footnotetext{
${ }^{8}$ Ibidem, s. 172-174.

9 J. Wołoszyn, op. cit., s. 84-86; W. Hanus, op. cit., s. 208 i n.

10 W. Syrek, op. cit., s. 192-194, 207-208; A. Szycht, Józef Cieśla „Topór”..., s. 112.

11 J. Wołoszyn, op. cit., s. 87-88; W. Hanus, op. cit., s. 226 i n., 244.
} 
Po ujęciu Cieśli „Topora” głównym celem funkcjonariuszy UB stała się ostateczna likwidacja reszty jego grupy. Powtórzono wcześniejszy podstęp z założeniem aparatury podsłuchowej. Zainstalowano ją u osoby podejrzewanej o współpracę z ukrywającymi się. Dzięki temu pozyskano wiedzę, że trzech poszukiwanych przebywało w zabudowaniach we wsi Szufnarowa w powiecie rzeszowskim. 25 II 1956 r. zostali oni osaczeni przez grupę operacyjna UB-KBW z Rzeszowa. W wyniku walki Ludwik Kuta poległ, a dwóch rannych (Władysław Dziedzic i Władysław Zamorski) zostało ujętych, a następnie skazanych odpowiednio na siedem i osiem lat więzienia ${ }^{12}$.

Bolesław Ciborowski, ostatni członek grupy przebywajacy na wolności, widząc, co stało się z jego współtowarzyszami, chcac za wszelką cenę wyrwać się z matni, podjął ryzykowną decyzję. Otóż 22 III 1956 r. zdemontował będący w jego posiadaniu pistolet maszynowy sten, zapakował go do walizki i wybrał się w podróż do Warszawy. W stolicy skierował się do redaktora naczelnego „Trybuny Ludu” - ówcześnie najważniejszego organu prasowego PZPR Jerzego Rawicza i „oddał się w jego ręce”. Wcześniej na łamach kierowanej przez siebie gazety Rawicz wzywał do ujawnienia ostatnich ukrywajacych się. Ciborowskiego przesłuchano i pozwolono mu wrócić do domu ${ }^{13}$.

$$
* * *
$$

Położenie osób pozostających na tzw. stopie nielegalnej miała zmienić przygotowana przez władze komunistyczne kolejna ustawa o amnestii, która weszła w życie 27 IV 1956 r. Była ona efektem postępującej w kraju destalinizacji i tzw. odwilży. Uwzględniono w niej czyny, których w poprzednich amnestiach nie wzięto pod uwagę (m.in. współpraca z okupantem niemieckim, szpiegostwo i sabotaż). Tym samym objęła ona w sumie nawet ok. 80 tys. osób. Na jej podstawie do października 1956 r. komunistyczne więzienia opuściło ok. 35 tys. więźniów. W większości byli to ludzie skazani z powodów politycznych. Pozostałym zmniejszono zasądzone wyroki, np. karę śmierci zamieniano na 15 lat więzienia, a karę dożywotniego pozbawienia wolności - na 12 lat więzienia ${ }^{14}$.

Do połowy czerwca 1956 r. na terenie całego kraju ujawniło się 228 osób. Jedynie ok. 90 z nich uznaje się za członków podziemia niepodległościowego. Spośród ujawnionych warto przybliżyć trzy najważniejsze postaci: dwie z Białostocczyzny i jedna z Rzeszowszczyzny. W pierwszym wypadku chodziło o por. Zachariasza Tarnowskiego „Kochanowskiego”, „Zawiszę” i st. sierż. Józefa Jankowskiego „Juranda”, „Jerzego”. Pierwszy z nich od 20 IX 1945 r. był komendantem Komendy Powiatu Narodowego Zjednoczenia Wojskowego

\footnotetext{
${ }_{12}$ M. Surdej, Szufnarowa 25 lutego 1956 r., „Wyklęci” 2016, nr 2, s. 19-23.

${ }^{13}$ W. Syrek, op. cit., s. 181-182.

${ }^{14}$ J. Dudek, Amnestia jako środek walki aparatu bezpieczeństwa z podziemiem niepodlegtościowym na przykładzie Lubelszczyzny, w: Komunistyczne amnestie lat 1945-1947 - drogi do „legalizacji” czy zagłady?, red. W.J. Muszyński, Warszawa 2012, s. 231.
} 
Bielsk Podlaski „Burza”. Drugi pełnił kilka różnych funkcji w owej komendzie, a na koniec był adiutantem por. Tarnowskiego. W ostatnich latach przed ujawnieniem istnienie komendy, na której czele stał por. Tarnowski, miało wymiar bardziej symboliczny niż realnej działalności konspiracyjnej. Chcąc skorzystać z ustawy o amnestii, a nie ufając miejscowym władzom bezpieczeństwa, 22 VIII 1956 r. z poczty w Perlejewie wysłali listem poleconym petycję do Rady Państwa „w sprawie naszego ujawnienia się i przywrócenia nam praw do legalnego życia”. Nie otrzymujac odpowiedzi i obawiając się, że list został przejęty przez UB, skierowali pismo do bielskiego i siemiatyckiego PUdsBP, w którym stwierdzali:

[...] niektórzy funkcjonariusze UB mówią, iż oni prędzej nas dostaną do swych rąk, niż my zdołamy się ujawnić. [...] Prosimy władze wyżej wymienionych Urzędów o pomoc, a nie utrudnianie w naszym ujawnieniu się i położenia kresu temu niebudującemu, szkodliwemu i marnotrawnemu trybowi naszego konspiracyjnego życia i przejścia do legalnego twórczego życia. [...] więc prosimy jeszcze raz Władze wyżej wspomnianych Urzędów Bezpieczeństwa o pomoc w tej sprawie i jeśli prośba nasza do Rady Państwa jest w ich posiadaniu, wysłania jej do Rady Państwa ${ }^{15}$.

12 IX 1956 r. obaj zjawili się w Prokuraturze Generalnej w Warszawie. Trzy dni później stawili się w Prokuraturze Wojewódzkiej w Białymstoku. W chwili ujawnienia por. Tarnowski miał 61 lat, a Jankowski - 42 lata. Obaj zostali zatrzymani na 48 godzin. Następnie sąd podjął decyzję, aby wobec Józefa Jankowskiego zastosować areszt tymczasowy. Kolejne dwa miesiące spędził on w białostockim więzieniu. Argumentowano to potrzebą dokładnego wyjaśnienia wszystkich szczegółów związanych z jego działalnością konspiracyjna. Po upływie wspomnianego okresu został zwolniony z aresztu i mógł wrócić do normalnego życia, choć pod szczegółowym nadzorem SB. Przez następne lata był inwigilowany przez funkcjonariuszy $\mathrm{SB}^{16}$.

Wcześniej, bo w czerwcu 1956 r. z amnestii skorzystała Jadwiga Krasowska „Ciotka”, która od września 1953 r. ukrywała się razem ze wspomniana wyżej dwójka, po tym jak 8 września UB ują jej męża Kazimierza Krasowskiego „Głuszca”. Na przestrzeni wcześniejszych lat był on dowódcą oddziału zbrojnego NZW. Stracono go 29 XII 1954 r. w białostockim więzieniu na mocy wyroku Wojskowego Sądu Rejonowego w Białymstoku ${ }^{17}$.

Na Rzeszowszczyźnie ważną postacią oporu antykomunistycznego w okresie powojennym był st. sierż. Aleksander Rusin „Olek”. Już w 1943 r. stał na

\footnotetext{
15 A. Chmielewska, J. Drozdowska, J. Gogolewska, W godzinie próby. Żołnierze podziemia niepodległościowego $w$ Białostockiem po 1944 roku i ich losy, wyd. 2 popr., Białystok-Warszawa 2018, s. 190.

${ }^{16}$ Ibidem, s. 188; M. Bechta, W.J. Muszyński, Przeciwko Pax Sovietica. Narodowe Zjednoczenie Wojskowe i struktury polityczne ruchu narodowego wobec rezimu komunistycznego 1944-1956, Warszawa 2017, s. 291.

17 A. Chmielewska, J. Drozdowska, J. Gogolewska, op. cit., s. 113-114, 180-187.
} 
czele grupy dywersyjnej AK. Po wojnie dowodził kilkunastoosobowym oddziałem partyzanckim podporządkowanym DSZ, a później uznał zwierzchnictwo dowódcy zgrupowania partyzanckiego WiN mjr. Hieronima Dekutowskiego „Zapory”. Ujawnił się 13 III 1947 r., a następnie opuścił Rzeszowszczyznę i osiadł w okolicach Lubina na Dolnym Śląsku. Prowadził tam własną kuźnię. Pod koniec lat czterdziestych XX w. zaczął być inwigilowany przez UB. W styczniu 1950 r. skrył się w lesie, dzięki czemu uniknął aresztowania. Wrócił w rodzinne strony i samotnie ukrywał się przez kolejne sześć lat. W $1953 \mathrm{r}$. wysłał petycję do Bolesława Bieruta, że mimo ujawnienia nadal jest prześladowany przez UB. Od 1955 r. formalnie poszukiwano go pod zarzutem nielegalnego posiadania broni. $23 \mathrm{~V} 1956 \mathrm{r}$. zgłosił się do Prokuratury Wojewódzkiej w Rzeszowie i ujawnił się. Śledztwo przeciwko niemu zostało ostatecznie umorzone w październiku 1956 r. Pomimo to przez następne lata był inwigilowany przez $\mathrm{SB}^{18}$.

$$
* * *
$$

Jednak nie wszyscy zdecydowali się na ujawnienie i podjęcie próby powrotu do normalnego życia. Odkrywając losy tych osób, możemy spróbować poznać ich indywidualną sytuację oraz motywy, które skłoniły ich bądź zmusiły do tego, aby ponad 10 lat po zakończeniu wojny nadal tkwić w ukryciu. Zważywszy, że było to życie w skrajnie niekorzystnych warunkach materialnych, w stanie ciagłego zagrożenia i poczuciu osaczenia, co miało poważny wpływ na ich samopoczucie psychiczne ${ }^{19}$. Co więcej, poznanie historii poszczególnych postaci może pozwolić na odnalezienie odpowiedzi na pytanie, dlaczego nie skorzystali oni z amnestii wiosna $1956 \mathrm{r}$. Wiedza o tym, co robili w trakcie ukrywania się po kwietniu 1956 r., umożliwi zastanowienie się nad tym, jak postrzegać charakter ich działalności? Czym ona w tym czasie była? Czy jedynie trwaniem, czy też występowały w niej jakieś aspekty działalności antykomunistycznej/antypaństwowej?

Trudno podać dokładną liczbę osób poszukiwanych przez UB/SB po kwietniu 1956 r., podejrzanych o działalność antypaństwową w szeregach podziemia niepodległościowego w Polsce po $1944 \mathrm{r}$. Problem ten zapewne będzie wymagał w przyszłości przeprowadzenia szczegółowych badań naukowych. Wiadomo, że w tej grupie poszukiwanych znajdowali się tacy, którzy posługując się sfałszowanymi danymi personalnymi, dotrwali do przemian politycznych w Polsce. Brakuje danych, jak licznej grupy obywateli mogło to dotyczyć.

\footnotetext{
${ }_{18}$ M. Surdej, Amnestie i akcja ujawnieniowa na Rzeszowszczyźnie w latach 1945-1956, w: Komunistyczne amnestie..., s. 250-251; idem, „Trzy konspiracje”. Historia Aleksandra Rusina ps. „Rusal”, Rzeszów-Warszawa 2020.

19 M. Mazur, Antykomunistycznego podziemia portret zbiorowy 1945-1956. Aspekty mentalno-psychologiczne, Warszawa-Lublin 2019, s. 432 i n.
} 
$\mathrm{Z}$ amnestii nie skorzystało i nadal się ukrywało co najmniej osiem osób: Antoni Dołęga „Znicz”, Wacław Dąbrowski „Tygrys”, Józef Franczak „Laluś”, „Lalek”, Andrzej Kiszka „Dąb”, Romuald Korwek „Orzech”, Michał Krupa „Wierzba”, Stanisław Marchewka „Ryba” i Tadeusz Wysocki „Zegar”. Spośród wymienionej ósemki czterech przebywało na pograniczu północno-wschodniego Mazowsza i północno-zachodniej Białostocczyzny (Dabrowski, Korwek, Marchewka, Wysocki), dwóch na terenie Lubelszczyzny (Dołęga, Franczak), a dwóch kolejnych na pograniczu Lubelszczyzny i Rzeszowszczyzny (Kiszka, Krupa). Spośród wymienionej ósemki tylko Dąbrowski, Marchewka i Wysocki razem się ukrywali. Natomiast pozostali trwali w ukryciu samodzielnie. Wspólnym mianownikiem łączacym ośmiu wyżej wspomnianych mężczyzn był fakt, że wszyscy oni rozpoczęli działalność podziemna, co prawda w różnych okresach, ale podczas okupacji niemieckiej.

Jeśli chodzi o ich wiek, to dwóch z nich urodziło się w przedziale 1900 1910, a po trzech w przedziałach 1911-1920 i 1921-1930. Najstarszy z nich był Korwek (ur. 1900 r.), a najmłodszy - Wysocki (ur. 1924 r.). Wszyscy wywodzili się ze wsi, a ich rodzice mieli kilkuhektarowe gospodarstwa rolne, które stanowiły podstawę utrzymania ich rodzin. Tylko rodzice Dąbrowskiego i Wysockiego gospodarowali na piętnastohektarowych gospodarstwach rolnych. Ojciec Michała Krupy dodatkowo pracował jako listonosz. Dwaj najstarsi (Korwek i Marchewka) pobierali nauki w szkole carskiej. Z ustaleń UB wynikało, że pierwszy z nich ukończył tylko jedną klasę, a Marchewka - trzy klasy szkoły powszechnej. Pozostali kształcili się w polskich szkołach w okresie międzywojennym. Prawdopodobnie z pozostałej szóstki czterech ukończyło siedmioklasową szkołę powszechną (Dołęga, Franczak, Krupa, Wysocki), Dąbrowski - sześć klas, a Kiszka pięć. Naukę kontynuował Franczak, który przed wybuchem wojny ukończył Szkołę Podoficerską Żandarmerii w Toruniu. Naukę w szkole średniej podją też Wysocki, ale przerwała ją wojna. Przed wojną jedynie Korwek i Marchewka zawarli małżeństwo. Korwek już po półtora roku został wdowcem - jego żona zmarła podczas ich pobytu w Brazylii. Po pewnym czasie wstapił $\mathrm{w}$ drugi związek małżeński (jego druga żona na krótko przed wybuchem wojny wyjechała do USA). W czasie okupacji związek małżeński zawarł Dołęga, a po zakończeniu wojny - Dąbrowski. Przed wybuchem wojny pracą zawodową zajmowali się najstarsi spośród wymienionej ósemki. Zarobku w Brazylii w latach trzydziestych XX w. szukał Korwek (był z zawodu cieśla); Marchewka prowadził sklep kolonialny w rodzinnej miejscowości Jeziorko k. Łomży. Na kilka miesięcy przed wybuchem wojny Franczak rozpoczął służbę jako żandarm w Równem na Wołyniu. Pozostali pomagali swoim rodzicom $\mathrm{w}$ pracach $\mathrm{w}$ gospodarstwach rolnych. Krupa, po tym jak jego ojciec - listonosz padł ofiara napadu, jako najstarszy z rodzeństwa musiał prowadzić rodzinne gospodarstwo. W latach trzydziestych 
Marchewka i Dołęga odbyli zasadniczą służbę wojskową oraz ukończyli w jej trakcie szkolenie podoficerskie. Powyższa dwójka oraz Franczak wzięli udział w walkach we wrześniu 1939 r. Franczak dostał się do niewoli sowieckiej, a Marchewka do niemieckiej, skąd udało im się zbiec ${ }^{20}$.

Nasza wiedza odnośnie do tego, co robili w czasie okupacji, jest w niektórych przypadkach bardzo skromna. Wszyscy wyżej wskazani przebywali w swoich rodzinnych okolicach. Tam też w różnych okresach okupacji włączyli się $\mathrm{w}$ działalność konspiracyjną. Większość z nich zaczynała służbę $\mathrm{w}$ podziemiu w szeregach ZWZ. Wyjątkami byli Kiszka, który początkowo należał do BCh oraz Wysocki, który w 1943 r. wstapił do Narodowych Sił Zbrojnych (NSZ). Franczak najprawdopodobniej na początku należał do Narodowej Organizacji Wojskowej/Narodowo-Ludowej Organizacji Wojskowejej, a dopiero potem do ZWZ. Z kolei Korwek w 1943 r. razem z innymi rozłamowcami, którzy również samowolnie opuścili szeregi AK (wcześniej działał w ZWZ), znalazł się w szeregach NSZ. Prawdopodobnie tylko Marchewka w latach 1939-1944 doświadczył działania dwóch systemów okupacyjnych. Zreszta przed czerwcem $1941 \mathrm{r}$. był poszukiwany przez NKWD, po tym jak sowieckie służby specjalne rozbiły siatkę konspiracyjną ZWZ na terenie powiatu łomżyńskiego. Ponowny kontakt z odbudowującymi się ogniwami ZWZ nawiązał dopiero po zajęciu tych terenów przez wojska niemieckie.

${ }^{20} \mathrm{Na}$ podstawie: D. Garbacz, Ostatni partyzant „Wotyniaka”, „Wyklęci” 2016, nr 2, s. 36; A. Szycht, Michał Krupa „Wierzba”, w: Ostatni komendanci..., s. 45; A. Pityński, Mój wujeknieztomny desperat. Por. Michat Krupa „Putkownik”, „Wierzba”(1920-1972), „Wyklęci” 2016, nr 2, s. 44; J. Karczewski, Niestusznie zapomniany. Romuald Korwek „Orzech”(1900-1961), „Wyklęci” 2016, nr 2, s. 58-59; J. Karczewski, R. Werelich, Ostatni Żotnierz Wyklęty? Antoni Dotęa (1915-1982?), „Wyklęci” 2016, nr 2, s. 107-108; S. Poleszak, Stanistaw Marchewka (1908-1957), w: Konspiracja i opór społeczny w Polsce 1944-1956. Stownik biograficzny, t. I, red. J. Żaryn, J.T. Żurek, Kraków-Warszawa-Wrocław 2002, s. 275; S. Poleszak, Podziemie antykomunistyczne w Eomżyńskiem i Grajewskiem (1944-1957), Warszawa 2004, s. 423, 425; idem, Andrzej Kiszka „Leszczyna”, Dab”, „Bogucki”, w: Ostatni komendanci..., s. 33; K. Sychowicz, Nie poddat się do końca. Stanistaw Marchewka „Ryba” (1908-1957), „Wyklęci” 2016, nr 2, s. 26; S. Poleszak, Józef Franczak (1918-1963), w: Konspiracja i opór społeczny $w$ Polsce 1944-1956. Stownik biograficzny, t. III, red. T. Balbus i in., KrakówWarszawa-Wrocław 2007, s. 151; Rozmowa Stanisława Kuźnika z Wacławem Szaconiem z 20 IV 2008 r., kopia w zbiorach autora.

${ }^{21}$ Pierwszy materiał filmowy pochodzi z 22 I 2016 r., natomiast drugi z 8 III 2019 r. W obu Szacoń powiedział, że 3 V 1942 r. został zaprzysiężony przez dyrektora szkoły w Żukowie, Tadeusza Chwostka, do Narodowej Organizacji Wojskowej. Świadkiem przysięgi miał być Józef Franczak. Nie zastanawiałoby to, gdyby nie fakt, że w rozmowie z 2008 r. podał, że Franczak był świadkiem jego zaprzysiężenia, ale do Narodowo-Ludowej Organizacji Wojskowej. Zob. https://www.youtube.com/watch?v=PKuxiMEpgUA (dostęp: 15 IV 2020); https://www.youtube.com/watch?v=FCBFUlS9KYk (dostęp: 15 IV 2020); https://www. polskieradio24.pl/130/7527/Artykul/2274034,Por-Waclaw-Szacon-Przyjaznilem-sie-z-Jozefem-Franczakiem-ps-Lalus (dostęp: 20 V 2020); Rozmowa Stanisława Kuźnika z Wacławem Szaconiem z 20 IV 2008 r., kopia w zbiorach autora. 
Brakuje szczegółowych danych co do ich aktywności konspiracyjnej w okresie okupacyjnym. Zdecydowana większość z nich to szeregowi członkowie w formacjach, do których przynależeli. Wyjątkiem był Stanisław Marchewka „Ryba”, który prawdopodobnie już od 1943 r. stał na czele plutonu AK w swojej rodzinnej miejscowości. Niewykluczone, że taką samą funkcję sprawował Józef Franczak „Laluś”22. Pluton liczył zazwyczaj ok. 30 ludzi. „Ryba” dowodził plutonem w ramach odtwarzanego przez obwód łomżyński 33 Pułku Piechoty AK. W miesiacach letnich $1944 \mathrm{r}$. brał udział w walkach pułku na nadnarwiańskich bagnach. W drugiej połowie sierpnia jego pluton jako jeden $\mathrm{z}$ ostatnich pododdziałów pułku został zdemobilizowany. W szeregach odtwarzanego przez obwód grajewski 9 Pułku Strzelców Konnych walczył Wacław Dąbrowski „Tygrys”, a Michał Krupa „Wierzba” w oddziale Narodowej Organizacji Wojskowej (NOW)-AK por. Franciszka Przysiężniaka „Ojca Jana”, a potem NOW Józefa Zadzierskiego „Wołyniaka”. Z chwilą wkroczenia Armii Czerwonej część z nich znalazła się w szeregach organizowanego przez PKWN ludowego WP (Dołęga, Franczak, Marchewka) czy też w MO (Kiszka, Krupa). W ciagu niespełna roku wszyscy oni zdezerterowali z formacji, w których służyli ${ }^{23}$.

W odniesieniu do działalności konspiracyjnej, jaka prowadzili w latach 1945-1947, posiadana wiedza ma różny stopień szczegółowości. Wydaje się, że w pełni uprawnionym stwierdzeniem będzie to, że na przestrzeni kilku miesięcy 1945 r. najbardziej aktywną walkę zbrojna prowadził ppor. cz.w. Stanisław Marchewka „Ryba”. Po samowolnym opuszczeniu jednostki WP w Dojlidach (wiele wskazuje, że stało się to na rozkaz jego przełożonego z konspiracji), wszedł w szeregi Armii Krajowej Obywatelskiej (w Okręgu Białystok nie wykonano rozkazu o rozwiąaniu AK, a AKO była jej kontynuatorka). Kolejno pełnił funkcję przewodnika samoobrony w rejonie łomżyńskim (dawniej dowódca Kedyw inspektoratu), szefa ochrony osobistej i adiutanta przewodnika rejonu mjr. Jana Tabortowskiego „Bruzdy”, a w okresie od maja do lipca 1945 r. dowodził kilkudziesięcioosobowym oddziałem partyzanckim. Brał też udział w kilku spektakularnych akcjach zbrojnych: odbiciu ze szpitala

${ }^{22}$ Nie udało się tego potwierdzić na podstawie zachowanej dokumentacji organizacyjnej. Na pewno pełnił funkcję dowódcy drużyny. Bardzo prawdopodobne, że mógł też być dowódca żandarmerii w plutonie. Więcej zob. S. Poleszak, Czy okupacyjna przeszłość sierż. Józefa Franczaka „Lalusia” miata wptyw na powojenne losy „ostatniego zbrojnego”? „Zagłada Żydów. Studia i Materiały" 2020, nr 16, s. 237-238.

${ }^{23} \mathrm{Na}$ podstawie: D. Garbacz, Wotyniak, legenda prawdziwa, wyd. 3 popr. i rozsz., Stalowa Wola 2008, s. 29; idem, Ostatni partyzant..., s. 37; A. Szycht, Michat Krupa „Wierzba”..., s. 45-46; A. Pityński, op. cit., s. 44; J. Karczewski, op. cit., s. 59; J. Karczewski, R. Werelich, op. cit., s. 108; S. Poleszak, Stanistaw Marchewka..., s. 275; idem, Jeden z wyklętych Major Jan Tabortowski „Bruzda”, Warszawa 1998, s. 114 i n.; J. Szcześniak, Jan Tabortowski „Bruzda”, w: Ostatni komendanci..., s. 141-145; K. Sychowicz, op. cit., s. 26; S. Poleszak, Podziemie antykomunistyczne..., s. 423, 425; idem, Andrzej Kiszka..., s. 33; idem, Józef Franczak..., s. 151; Rozmowa Stanisława Kuźnika z Wacławem Szaconiem z 20 IV 2008 r., kopia w zbiorach autora. 
w Białymstoku łączniczki Franciszki Ramotowskiej „Iskry”, rozbiciu grupy operacyjnej Komendy Głównej MO pod Wyrzykami oraz przede wszystkim w operacji z 8 na 9 V 1945 r., kiedy opanowano i rozbito instytucje administracji komunistycznej w powiatowym Grajewie. Z aresztów uwolniono ok. stu więzionych. Dowodził wtedy grupą uderzeniowa, która zdobyła miejscowy PUBP. W siatce terenowej Obwodu AKO Grajewo działał Wacław Dąbrowski „Tygrys”, który również uczestniczył we wspomnianej akcji na Grajewo. Był partyzantem grupy zdobywającej siedzibę Komendy Powiatowej MO. Czynnym członkiem oddziału partyzanckiego NZW ppor. Józefa Zadzierskiego „Wołyniaka” operujaccego na Zasaniu został Michał Krupa „Wierzba”. Pełnił on $\mathrm{w}$ oddziale funkcję erkaemisty. Brał m.in. udział $\mathrm{w}$ bitwie $\mathrm{z}$ ekspedycja NKWD pod Kuryłówką. Bronił z oddziałem ludności Zasania przed atakami ukraińskiej partyzantki nacjonalistycznej, ale zapewne uczestniczył też $\mathrm{w}$ akcjach pacyfikacyjnych skierowanych przeciwko cywilnej ludności ukraińskiej (Piskorowice). Z oddziałem tym współpracował Andrzej Kiszka.

Funkcję zastępcy dowódcy kompanii, a następnie jej dowódcy pełnił Romuald Korwek „Orzech”. Wchodziła ona w skład I batalionu Komendy Powiatu NZW „Orawa” (część powiatu ostrołęckiego). Jako szeregowy członek siatki terenowej Komendy Powiatu NSZ/NZW Grajewo służył Tadeusz Wysocki „Zegar”. Z kolei w łukowskim obwodzie DSZ, a potem WiN działał Antoni Dołęga „Znicz”. Jeśli chodzi o Józefa Franczaka „Lalusia”, to wiadomo, że w drugiej połowie $1944 \mathrm{r}$. stacjonował ze swoją jednostką ludowego WP w Kąkolewnicy w powiecie radzyńskim. Prawdopodobnie na początku $1945 \mathrm{r}$. zdezerterował z szeregów WP. Po zakończeniu wojny nie wrócił w rodzinne strony, a na krótko osiadł w Sopocie, gdzie pracował w miejscowej spółdzielni marynarzy. Najpewniej posługiwał się wtedy fałszywymi dokumentami na nazwisko Józef Bagiński. Prawdopodobnie rozpoznany przez kogoś, zagrożony aresztowaniem, pod koniec 1945 lub na początku 1946 r. wrócił na Lubelszczyznę. 16 VI 1946 r. został ujęty przez grupę operacyjna Wojewódzkiego Urzędu Bezpieczeństwa Publicznego (WUBP) z Lublina. W czasie konwojowania wraz z innymi pojmanymi uwolnił się z więzów i zaatakował konwojentów, zabierając im broń. W czasie walki czworo członków grupy operacyjnej zginęło, a pojmani, przypuszczalnie 10, zbiegli. Prawdopodobnie od początku 1947 r. dołączył do oddziału kpt. Zdzisława Brońskiego „Uskoka”, gdzie dowodził kilkuosobowym patrolem partyzanckim.

Pomimo wielkich wątpliwości związanych z tym, czy skorzystać z uchwalonej 22 II 1947 r. przez Sejm Ustawodawczy ustawy o amnestii, aż sześciu spośród wspomnianej ósemki konspiratorów zaryzykowało i ujawniło się. Byli to: Dąbrowski, Dołęga, Kiszka, Korwek, Marchewka i Wysocki. Jednak już po kilku miesiącach trzech z nich (Dołęga, Kiszka, Korwek) ponownie znalazło się na stopie nielegalnej, a kolejnych dwóch (Dąbrowski, Wysocki) w ciagu następnych 2-3 lat. Był to efekt działań UB, który na skutek najmniejszych podejrzeń (np. że amnestionowany utrzymywał kontakty z nieujawnionymi 
kolegami czy też posiadał o nich jakąkolwiek wiedzę) mógł wzywać na przesłuchanie, nękać „odwiedzinami”, próbować aresztować czy pozyskiwać do tajnej współpracy. Znalazłszy się w takiej sytuacji, dochodzili do wniosku, że jedyny sposób na ocalenie stanowiło ukrywanie się. Często na początku nie była to decyzja o trwałym powrocie „do lasu”. Chodziło raczej - jak to sami określali - o „zejście z oczu władzy”. Ukrycie się, przeczekanie i podjęcie próby powrotu do legalnego życia. Jednak ten pierwszy krok powodował, że o powrót nie było łatwo. Trudności potęgowały się wraz z wejściem w nielegalne posiadanie broni, przynależnością do „bandy terrorystyczno-rabunkowej” czy też udziałem w różnego rodzaju akcjach ${ }^{24}$.

Ostatnią osobą zmuszoną niejako do powrotu do lasu był Stanisław Marchewka. Na początku 1946 r. opuścił on szeregi podziemia i wyjechał do Łodzi, gdzie próbował normalnie żyć, utrzymując się z handlu. W kwietniu $1947 \mathrm{r}$. stawił się w Łomży przed miejscową komisja amnestyjna, po czym powrócił do Łodzi. Funkcjonariusze UB przypomnieli sobie o nim pod koniec $1952 \mathrm{r}$. Zaplanowali, aby wykorzystać go w rozgrywce operacyjnej przeciwko grupie jego byłego dowódcy i przyjaciela mjr. Jana Tabortowskiego „Bruzdy”, który po ujawnieniu się w marcu 1947 r. przez trzy kolejne lata mieszkał w Warszawie. Tabortowski podją pracę oraz próbował studiować w Szkole Głównej Handlowej. Inwigilowany przez UB, słusznie obawiając się aresztowania, wiosną 1950 r. opuścił stolicę. Nie widząc możliwości powrotu do legalnego życia, po roku utworzył kilkuosobową grupę przetrwania. Funkcjonariusze komunistycznego aparatu represji zmusili „Rybę” do podpisania deklaracji współpracy i postawili przed nim zadanie nawiązania kontaktu z mjr. Tabortowskim, a następnie wskazanie UB miejsca jego pobytu. W chwili gdy doszło do spotkania, Marchewka wyjawił prawdziwy powód przybycia, a następnie przyłączył się do oddziałku. W tym czasie kadrowymi członkami tej grupy byli już Dąbrowski „Tygrys” i Wysocki „Zegar”. Na tle innych grup przetrwania działających w Polsce pod koniec lat czterdziestych i na początku lat pięćdziesiątych, jeśli chodzi o skład personalny, była wyjątkowa. Oprócz wymienionych wcześniej mjr. „Bruzdy” i ppor. „Ryby” należał do niej kpt. Stanisław Cieślewski „Lipiec”, były komendant Obwodu AK Łomża oraz dowódca odtwarzanego 33 Pułku Piechoty AK, ponadto na krótko związał się z nią ostatni zastępca prezesa Obwodu WiN Łomża, ppor. Józef Ramotowski „Rawicz”25.

${ }^{24} \mathrm{Na}$ podstawie: D. Garbacz, Ostatni partyzant..., s. 37-39; A. Szycht, Michat Krupa „Wierzba”..., s. 47 i n.; J. Karczewski, op. cit., s. 59-61; J. Karczewski, R. Werelich, op. cit., s. 108; S. Poleszak, Stanisław Marchewka..., s. 275-276; idem, Jeden z wyklętych..., s. 146, 159 i n.; K. Sychowicz, op. cit., s. 27-28; S. Poleszak, Podziemie antykomunistyczne..., s. 423, 425; idem, Andrzej Kiszka..., s. 33-34; idem, Józef Franczak..., s. 152; idem, Ostatni leśny. Sierż. Józef Franczak „Laluś, „Lalek”, (1918-1963), „Wyklęci” 2016, nr 2, s. 82-83; Rozmowa Stanisława Kuźnika z Wacławem Szaconiem z 20 IV 2008 r., kopia w zbiorach autora.

${ }^{25}$ S. Poleszak, Jeden z wyklętych..., s. 258-260; M. Mazur, op. cit., s. 430-431. 
Bardzo różnie wyglądała mapa oddziałów, do których trafili członkowie wspomnianej ośmioosobowej grupy ostatnich partyzantów. Romuald Korwek „Orzech” nawiązał kontakt z chor. Hieronimem Rogińskim „Rogiem”, komendantem Powiatu NZW „Łużyca”-„Łuków” i został jednym z członków patrolu Pogotowia Akcji Specjalnej. Komenda ta do lipca 1949 r. wchodziła w skład Okręgu „Orzeł”, obejmującego Kurpiowszczyznę oraz powiaty położone na północ od Warszawy. Michał Krupa „Wierzba” nadal przebywał w szeregach oddziału NZW, którym po śmierci ppor. Józefa Zadzierskiego „Wołyniaka” dowodził chor. Adam Kusz „Garbaty”. Pod koniec 1949 r. dołączył do niego również Andrzej Kiszka „Dąb”. Grupa ta nie posiadała żadnej zwierzchności organizacyjnej. Z kolei sierż. Józef Franczak „Laluś” do połowy 1948 r. pełnił funkcję dowódcy kilkuosobowego patrolu w powinowskim oddziale kpt. Zdzisława Brońskiego „Uskoka”. Od początku 1949 r. przez następne cztery lata miał luźny kontakt z innymi partyzantami, a od $1953 \mathrm{r}$. ukrywał się samotnie. Początkowo dowódcą również takiego kilkuosobowego patrolu w powinowskim oddziale na terenie powiatu łukowskiego był chor. Antoni Dołęga „Znicz”26.

Jeśli chodzi o aktywność patrolu sierż. „Lalusia”, to przeprowadził on kilka akcji, o których głośno było w rejonie jego działania. Mianowicie 24 VIII 1947 r. oddziałek liczący 6-7 ludzi wkroczył do Gardzienic w powiecie krasnostawskim, gdzie odbywała się taneczna zabawa dożynkowa. Zastrzelili komendanta posterunku MO w Rybczewicach. Dwaj pozostali milicjanci podjęli obronę. Doszło do strzelaniny, w wyniku której zginął postronny uczestnik zabawy, a kilka innych osób zostało rannych. Następnie 22 X 1947 r. patrol podstępem rozbroił posterunek MO w Wysokiem w powiecie krasnostawskim. Po czym zastrzelono miejscowego naczelnika poczty, który równocześnie był członkiem PPR i pełnił funkcję komendanta gminnego ORMO. Ponadto partyzanci zabrali towary z miejscowego sklepu Samopomocy Chłopskiej².

Działalność patrolu zakończyła się 13 V 1948 r. Pięciu partyzantów przemieszczając się furmanka, wpadło w zasadzkę grupy operacyjnej funkcjonariusza UB i milicjantów z posterunku MO w Krzczonowie. W wyniku ostrzału dwóch „leśnych” zginęło, a dwóch zostało rannych (jeden z nich w wyniku odniesionych ran zmarł) ${ }^{28}$.

${ }^{26}$ Więcej zob. D. Garbacz, Ostatni partyzant..., s. 38-40; J. Karczewski, op. cit., s. 60-62; S. Poleszak, Andrzej Kiszka..., s. 34; J. Kopiński, Podziemie antykomunistyczne w powiecie tukowskim w latach 1944-1982. Zarys problematyki, Łuków 2018, s. 22-37; S. Poleszak, Ostatni leśny..., s. 83; A. Szycht, Józef Cieśla „Wierzba”..., s. 54-57.

${ }_{27}$ Archiwum Instytutu Pamięci Narodowej, Oddział w Lublinie (dalej: AIPN Lu), 19/225, Akta sprawy karnej Władysława Domonia i in., Raport PUBP w Krasnymstawie z 23 X 1947 r., k. 168; S. Poleszak, Ostatni leśny..., s. 84.

${ }^{28}$ AIPN Lu, 043/15, Raporty specjalne, informacje oraz telefonogramy dotyczące napadów rabunkowych oraz przeprowadzonych operacji Wydziału III WUBP Lublin za okres od 10 I 1948 do 24 XII 1948 r., Raport specjalny w sprawie potyczki z bandą Franczaka w dniu 13 V 1948 r., szefa WUBP w Lublinie mjr. Franciszka Zalewskiego do Departamentu III MBP w Warszawie z 25 V 1948 r., k. 73. 
Równie aktywną działalność zbrojną na terenie powiatu łukowskiego prowadził oddział ppor. Józefa Matusza (vel Romana Dawickiego) „Lonta”, w którym funkcję dowódcy patrolu, później zastępcy dowódcy, a w końcu dowódcy oddziału po śmierci ppor. „Lonta” w grudniu 1951 r. pełnił chor. Antoni Dołęga „Znicz”. Na początku 1952 r. podlegało mu jeszcze kilkunastu partyzantów. Łukowski PUBP długo nie mógł sobie poradzić z rozpracowaniem jego grupy. Dopiero w 1954 r. oddział poniósł znaczne straty. Dzięki informacjom od TW „Jankowskiego” 23 maja w kolonii Bystrzyca k. Wojcieszkowa, w powiecie łukowskim, stuosiemdziesięcioosobowa grupa operacyjna UB-KBW otoczyła i wystrzelała trzyosobowy patrol Wacława Skwary. Pod koniec tego roku UB ujął kolejnych trzech partyzantów, w tym dowódcę patrolu Teodora Szabelskiego. W październiku 1955 r. dwóch partyzantów ujawniło się w PUBP w Łukowie i po kilku przesłuchaniach zostało zwolnionych ${ }^{29}$. Jedynym ukrywajacym się partyzantem pozostawał „Znicz”.

Warto podkreślić, że wszyscy oni kontynuowali działalność antykomunistyczna po 1947 r. na terenach, z którymi byli związani rodzinnie, towarzysko, prowadzili wcześniejsze działania w czasie okupacji niemieckiej oraz przed amnestią z wiosny $1947 \mathrm{r}$.

$$
* * *
$$

Nasuwa się pytanie, co spowodowało, że tych ośmiu konspiratorów nie ujawniło się wiosną 1956 r.? Czy wynikało to tylko z nieufności do władzy komunistycznej, ich cech charakteru, a może niepełnej wiedzy, co sprawiało, że nie mogli podjaćc racjonalnych decyzji? Czy też jednak z powodu popełnionych czynów, których w przekonaniu konspiratorów amnestia nie obejmowałaby?

Treść ustawy o amnestii z 27 IV 1956 r. świadczy o tym, że była ona skierowana przede wszystkim do osób już skazanych (wyjątek stanowił art. 8). Ponadto zawarte $\mathrm{w}$ niej przepisy wskazują na to, że wobec ujawniającego się nadal miano prowadzić postępowanie, które mogło zakończyć się wnioskiem o umorzenie lub orzeczenie kary, i dopiero wtedy powinny zostać zastosowane przepisy amnestii (art. 3) ${ }^{30}$. Należy jednak pamiętać, że w praktyce wygladało to inaczej, o czym świadczą przykłady przedstawione wcześniej, jak i te o których będzie mowa w dalszej części tekstu (Dąbrowski, Korwek, Wysocki).

Wydaje się, że u zdecydowanej większości konspiratorów przeważyły nieufność i brak wiary, że intencje władzy komunistycznej są szczere. Tu najlepszy punkt odniesienia dla nich stanowiła akcja ujawnienia przeprowadzona wiosną 1947 r., kiedy pomimo obietnic ze strony władz wielu ujawnionych stało się ofiarami represji (w tym niektórzy z opisywanych). Niewykluczone, że w niektórych przypadkach zwyciężyło przekonanie, że nie wszystkie

\footnotetext{
${ }^{29}$ J. Kopiński, Podziemie antykomunistyczne..., s. 39-42.

${ }^{30}$ Ustawa z 27 IV 1956 r. o amnestii: http://isap.sejm.gov.pl/isap.nsf/DocDetails.xsp?id= WDU19560110057 (dostęp: III 2020).
} 
partyzanckie czyny z przeszłości władza jest w stanie puścić $\mathrm{w}$ niepamięć. Dla przykładu Marchewka mógł zakładać, że akt „zdrady”, jakiego dopuścił się wobec UB w 1953 r., nie zostałby mu wybaczony. Co istotne, w trakcie akcji, w których brał udział, zginęło dwóch funkcjonariuszy MO (8 IX 1953 r. w Ławsku; 23 VIII 1954 r. w Przytułach), a funkcjonariusz UB i członek ORMO zostali ranni ${ }^{31}$. Jego dwaj towarzysze broni, Dąbrowski (posiadał kilkunastohektarowe gospodarstwo rolne, którym zajmowała się jego żona) i Wysocki, byli zainteresowani powrotem do legalnego życia. W grudniu $1956 \mathrm{r}$. żona Dabrowskiego, Jadwiga i siostra Wysockiego, Eugenia napisały prośby zaadresowane do I sekretarza KC PZPR Władysława Gomułki, w których prosiły o umożliwienie ujawnienia się męża i brata. Jednak decydujacym czynnikiem była stanowcza postawa zwierzchnika, której oni nie chcieli się sprzeciwiać, co więcej, przez długi okres odmawiali też ujawnienia kosztem wydania swojego dowódcy ${ }^{32}$. Z brakiem wiary $\mathrm{w}$ dobre intencje władzy komunistycznej mamy do czynienia w przypadku Korwka. Już w 1957 r. dotarła do niego informacja, że objęła go amnestia. Zapewniano go tė̇, że śledztwo w jego sprawie zostało umorzone. Nadal w to nie wierzył i żądał gwarancji bezpieczeństwa ${ }^{33}$. Podobną nieufność wykazali Dołega, Franczak, Krupa i Kiszka. W przypadku tego ostatniego należy wziąć pod uwagę fakt, że jesienia 1954 r. zastrzelił sekretarza Podstawowej Organizacji Partyjnej PZPR w Rataju Ordynackim, więc miał powód, by sądzić, że ów czyn nie pozostanie bez konsekwencji prawnych, nawet w sytuacji ujawnienia. Kiszka w relacji kilkakrotnie podkreślił jeszcze jeden czynnik - strach przed torturami. Bał się ich i tak o tym mówił: „tak samo i ja w bunkrze. Wiedziałem, że nie tego, to podniosłem wieko i żem się poddał, bo wiedziałem, że nie bija, a jakby bili, to bym się nie poddał. No i tyle" ${ }^{34}$.

Zapewne nie bez znaczenia pozostawał funkcjonujący w niektórych kręgach społeczeństwa (również w podziemiu) pogląd, że rządy w Polsce sprawowała „żydokomuna”. Żydów postrzegano jako oddanych sojuszników ustroju komunistycznego, a tym samym wrogów podziemia ${ }^{35}$.

31 S. Poleszak, Jeden z wyklętych..., s. 265-266, 273-274.

32 AIPN Bi, 0156/1/5, Akta grupowego rozpracowania agenturalnego kryptonim „Biebrza” dotyczące Stanisława Marchewki „Ryby”, Plan przedsięwzięć operacyjnych zmierzających do rozpracowania „bandy” „Ryby”, Białystok, 25 I 1957 r., k. 243-244.

33 J. Karczewski, op. cit., s. 62.

${ }^{34}$ Relacja Andrzeja Kiszki z 12 XII 2009 r., w zbiorach autora.

${ }^{35}$ Zob. K. Kersten, Polacy. Żydzi. Komunizm. Anatomia pótprawd 1939-68, Warszawa 1992; A. Paczkowski, Żydzi w UB: próba weryfikacji stereotypu, w: Komunizm. Ideologia, system, ludzie, red. T. Szarota, Warszawa 2001, s. 192-204; M.J. Chodakiewicz, Żydzi i Polacy 1918-1955. Wspótistnienie - zagłada - komunizm, Warszawa 2002. Stereotyp „żydokumuny”, szczególnie w odniesieniu do Żydów, którzy „utrwalali” władzę ludową w Polsce, jest widoczny na kartach pamiętnika Zdzisława Brońskiego „Uskoka”. Zob. Z. Broński „Uskok”, Pamiętnik (wrzesień 1939 - maj 1949), red. S. Poleszak, wyd. 2 rozsz. i popr., Lublin-Warszawa 2015. 
Wydaje się, że o wiele bardziej skomplikowana była sytuacja Józefa Franczaka $^{36}$. W latach pięćdziesiątych XX w. toczyły się dwa śledztwa, w których jako jedyny lub jeden $\mathrm{z}$ kilku pojawił się zarzut podejrzenia popełnienia przestępstwa wobec osób narodowości żydowskiej, a w których jako współpodejrzany występował Franczak ${ }^{37}$. Pierwsze z nich dotyczyło podejrzenia udziału w pojmaniu i oddaniu w ręce niemieckiej żandarmerii w Piaskach żydowskiego krawca Szmula Helfmana ${ }^{38}$. Po tym, jak ktoś dowiózł go na posterunek żandarmerii, został powieszony przez miejscowego żandarma Daniela Schultza. Wydarzenie to miało miejsce na przełomie 1943 i 1944 r. Franczaka zeznaniami obciążył Franciszek Beć, były podkomendny „Lalusia” w AK, a po wojnie aktywny „utrwalacz władzy ludowej” (członek PPR/PZPR, komendant wiejskiego ORMO). W czasie gdy składał obciążające Franczaka zeznania, pracował w KW PPR, a później KW PZPR w Lublinie. Według jego wersji Franczak wraz z innym nieznanym mu mężczyzną mieli złapać Helfmana i odwieźć go furmanką do Piasków. Treść złożonych zeznań różniła się między sobą. W pierwszym protokole przesłuchania oświadczył, że o przebiegu zdarzenia opowiedział mu sam Franczak. Trzy lata później podał, że był to ktoś zupełnie inny ${ }^{39}$. Niewykluczone, że Beć obciażył Franczaka, by uwiarygodnić się wobec swoich mocodawców (lub odwrócić uwagę od faktycznych sprawców) ${ }^{40}$.

${ }^{36}$ Szczegółowo opisałem to w artykule: S. Poleszak, Czy okupacyjna przeszłość..., s. 233-277. $\mathrm{Na}$ potrzeby niniejszego tekstu dokonałem jedynie krótkiego omówienia.

${ }^{37}$ Oba śledztwa prowadzone były na podstawie Dekretu Polskiego Komitetu Wyzwolenia Narodowego z dnia 31 sierpnia 1944 r. o wymiarze kary dla faszystowsko-hitlerowskich zbrodniarzy winnych zabójstw i znęcania się nad ludnością cywilną i jeńcami oraz dla zdrajców Narodu Polskiego: http://isap.sejm.gov.pl/isap.nsf/DocDetails.xsp?id=WDU19440040016 (dostęp: III 2020). Pierwsze z nich zakwalifikowano jako czyn objęty art. $1 \S 2$, drugie zaś jako czyn objęty art. $1 \S 1$. Żadnego z nich nie obejmowała amnestia z 22 II $1947 \mathrm{r}$. Sytuację w tym zakresie odnośnie do art. $1 \S 2$ zmieniła ustawa o amnestii z 27 IV 1956 r.

38 Już po zakończeniu prac nad artykułem Ośmiu ostatnich... ukazał się tekst polemiczny z opracowaniem S. Poleszak, Czy okupacyjna przeszłość..., autorstwa P. Niwińskiego i T. Łabuszewskiego. Wydaje się, że najważniejszym ustaleniem wspomnianych autorów jest to, że latach 1947-1949 toczyło się śledztwo w sprawie o wydanie Szmula Helfmana Niemcom, w którym podejrzanym o ten czyn był Franciszek Hochman, były policjant z posterunku w Biskupicach, a w okresie powojennym chorąży w ludowym WP. Zawiadomienie w tej sprawie złożył krewny Szmula, Chil Helfman. Twierdził on, że wraz z Szmulem byli członkami oddziału partyzanckiego sowiecko-żydowsko-polskiego. Prawdopodobnie w 1949 r. Chil Helfman opuścił Polskę, co zapewne miało poważny wpływ na to, że nie kontynuowano działań mających wyjaśnić okoliczności śmierci jego krewnego. Więcej zob. P. Niwiński, T. Łabuszewski, „Sprawa” Józefa Franczaka - czyli historia alternatywna (w zwiqzku z praca Stawomira Poleszaka), Czy okupacyjna przeszłość sierż. Józefa Franczaka „Lalusia” miała wptyw na powojenne losy „ostatniego zbrojnego”?, „Zagłada Żydów. Studia i materiaty”, $n r$ 16, 2020, s. 233-277, „Pamięć i Sprawiedliwość” 2021, nr 1 (37), s. 675 i n.

39 S. Poleszak, Czy okupacyjna przeszłość..., s. 251-252, 254.

${ }^{40}$ Przygotowując tekst Czy okupacyjna przeszłość..., rozmawiałem z Maksymilianem Jaroszem oraz Czesławem Nowakiem. Wspominali oni, że plotki o udziale Franczaka pojawiały 
Analiza wytworzonej w tej sprawie dokumentacji skłania do wniosku, że do śledztwa nie przywiązywano zbyt dużej wagi. Czynności śledcze prowadził milicjant z posterunku MO w Piaskach, w stopniu kaprala. Poczynione przez niego ustalenia różniły się zasadniczo od wersji podanej przez Becia. Jego zdaniem za ów czyn miało odpowiadać pięciu mieszkańców Majdanka Kozickiego (nie było wśród nich Franczaka) niedaleko Piasków, w powiecie lubelskim. Śledztwo rozpoczęto w maju 1950 r., a zakończono w grudniu 1950 r. Wobec czterech podejrzanych (jeden wcześniej zmarł) Prokuratura Wojewódzka w Lublinie umorzyła śledztwo z braku dowodów, a wobec Franczaka z powodu nieujęcia go. Jednocześnie wszczęto poszukiwania, o czym informowano w „Gazetce Poszukiwanych”, a 20 X 1951 r. rozesłano za nim list gończy ${ }^{41}$. Pismo o formalnym odwołaniu poszukiwań zostało sporządzone 23 VII 1956 r. $^{42}$ Możemy przypuszczać, że świadomość wydanego listu gończego nie była okolicznością zachęcającą do rozważań na temat skorzystania $\mathrm{z}$ amnestii.

Drugie śledztwo dotyczyło wydarzeń z lutego 1943 r. w Skrzynicach-Kolonii, wiosce oddalonej o $10 \mathrm{~km}$ od Kozic Górnych, rodzinnej miejscowości Franczaka. W jednym z gospodarstw wraz z Władysławem Beciem natknęli się na kwaterująca tam część trzydziestoosobowej żydowskiej grupy przetrwania. Nieopodal na Franczaka i Becia czekała podwoda z Franciszkiem Beciem i Władysławem Siudziakiem (furman). Pierwszy raz byli tam dzień wcześniej, wypytując gospodynię o to, czy przebywają u nich Żydzi (tak zeznał jeden $\mathrm{z}$ domowników, z kolei konspiratorzy w rozmowie między sobą wspominali o odbiorze amunicji). Na podwórzu natknęli się na żydowską wartę i zostali zaprowadzeni do domu mieszkalnego. Mieli przy sobie ukrytą broń krótka i granaty. W trakcie rewidowania ich udało się im wydobyć broń. Zabili dwóch Żydów, zabrali trzy karabiny, kilka granatów i uciekli ${ }^{43}$. Dopiero po 10 latach, w 1955 r., jeden z uczestników akcji (furman) złożył szczegółowe

się w okolicy. Obaj rozmówcy byli sceptyczni co do ich prawdziwości. Co więcej, Czesław Nowak twierdził, że rozpuszczano je w efekcie zmowy ludzi chcaccych obarczyć odpowiedzialnością Franczaka. Relacja Maksymiliana Jarosza z 13 IX 2019 r., w zbiorach autora; relacja Czesława Nowaka z 13 IX 2019 r., w zbiorach autora.

${ }^{41}$ S. Poleszak, Czy okupacyjna przeszłość..., s. 252-255; AIPN Lu, 341/30, Akta prokuratora Sąu Apelacyjnego w Lublinie w sprawie Józefa Franczaka, Wniosek o umorzenie śledztwa, 27 XII 1950 r., k. 33-34.

${ }^{42}$ S. Poleszak, Czy okupacyjna przeszłość..., s. 274.

${ }^{43}$ Ibidem, s. 238 i n. W tym czasie Józef Franczak „Laluś” był zapewne dowódcą drużyny. Zachowana dokumentacja może wskazywać, że wraz z drużyną wykonywał działania mające na celu odbieranie broni ludności niezorganizowanej. Ibidem, s. 262. Niewykluczone, że powyżej opisane zdarzenie stanowiło następstwo podobnej aktywności, tyle że w odniesieniu do żydowskiej grupy przetrwania. Stosunek struktur i oddziałów AK do tych grup był zazwyczaj negatywny. Więcej zob. A. Puławski, Postrzeganie żydowskich oddziałów partyzanckich przez Armię Krajowa i Delegaturę Rzqdu RP na Kraj, „Pamięć i Sprawiedliwość" 2003, nr 2 (4), s. 271-300. 
zeznania w tej sprawie, które niedługo potem zaginęły. Zapewne nie był to przypadek, gdyż zeznania obciążały m.in. Władysława Becia, którego UB zarejestrował jako $\mathrm{TW}^{44}$. Z dużą dozą prawdopodobieństwa należy założyć, że wiadomość o aktywności Siudziaka w tej sprawie była znana w okolicy i dotarła również do Franczaka. Co mogło nie pozostawać bez wpływu na jego decyzję w sprawie ujawnienia się.

Już trzy dni po wejściu w życie ustawy o amnestii, czyli 30 IV 1956 r. ponownie wszczęto śledztwo w sprawie przestępstw, o których dokonanie podejrzewano Franczaka. W czerwcu postawiono mu sześć zarzutów. Pierwszy odnosił się właśnie do zdarzenia w Skrzynicach-Kolonii. Następne dotyczyły tego, że od wyzwolenia do lutego 1953 r. był członkiem AK-WiN, pełniąc funkcję dowódcy patrolu; latem 1951 r. w miejscowości Passów wraz z Janem Łuciem i Zbigniewem Pielakiem zastrzelił członka PZPR Franciszka Drygałę oraz podpalił należące do niego zabudowania; w lutym 1953 r. w Piaskach wspólnie z Pielakiem i Stanisławem Kuchciewiczem „Wiktorem” brał udział w napadzie rabunkowym na miejscową Gminna Kasę Spółdzielczą Samopomocy Chłopskiej, podczas którego zginał komendant miejscowego posterunku, a dwóch milicjantów zostało rannych. Ostatni zarzut odnosił się do nielegalnego posiadania kilku jednostek broni przez cały czas ukrywania się ${ }^{45}$. Pozostawanie Franczaka na wolności spowodowało, że materiały ze śledztwa w sprawie zajścia w Skrzynicach-Kolonii przeciwko Beciowi postanowiono wyłączyć do odrębnego śledztwa. Sprawa zakończyła się 27 V 1957 r. wyrokiem uniewinniajaccym ${ }^{46}$.

O tym, że zdarzenie w Skrzynicach-Kolonii mogło mieć wpływ na powojenne losy „ostatniego zbrojnego”, wypowiedział się jego bliski współtowarzysz z powojennej konspiracji - Wacław Szacoń „Czarny”. Odnoszac się do problemu nieskorzystania przez „Lalusia” z możliwości ujawnienia się, stwierdził:

${ }^{44}$ S. Poleszak, Czy okupacyjna przeszłość..., s. 249, 270. Prawdopodobnie już w latach wcześniejszych Siudziak starał się zainteresować tą sprawą UB, a potwierdzać to moga groźby, które otrzymywał listownie. Ibidem, s. 248.

${ }^{45}$ Ibidem, s. 250-251. Zarzuty, które postawiono Franczakowi, odnosiły się do art. 1 pkt. 1 dekretu z 31 VIII 1944 r. (przewidywał karę śmierci); art. 86 § KKWP (przewidywał karę od 5 lat więzienia do kary śmierci); art. 1 § 2 i 3 dekretu z 13 VI 1946 r. (§ 2 przewidywał karę od 5 lat do dożywocia, a $§ 3$ od 10 lat więzienia lub dożywocie albo karę śmierci); art. 4 $\S 1$ dekretu z 13 VI 1946 r. (przewidywał karę od 5 lat więzienia lub dożywocie albo karę śmierci). Najmniej groźne, jeśli chodzi o wysokość kary, były art. $215 \S 1$ kk i art. 259 kk. Zob. Dekret Polskiego Komitetu Wyzwolenia Narodowego z dnia 31 sierpnia 1944..., http://isap.sejm.gov.pl/isap.nsf/DocDetails.xsp?id=WDU19440040016 (dostęp: III 2020); Dekret z dnia 13 czerwca 1946 r. o przestępstwach szczególnie niebezpiecznych w okresie odbudowy Państwa: http://isap.sejm.gov.pl/isap.nsf/DocDetails.xsp?id=WDU19460300192 (dostęp: III 2020); Dekret Polskiego Komitetu Wyzwolenia Narodowego z dnia 23 września 1944 r. - Kodeks Karny Wojska Polskiego: https://isap.sejm.gov.pl/isap.nsf/DocDetails. xsp?id=WDU19440060027 (dostęp: III 2020).

${ }^{46}$ S. Poleszak, Czy okupacyjna przeszłość..., s. 251. 
„[...] Józkowi chodziło o to... on się bał tego zajścia z Żydami w Kolonii Skrzynickiej. [...] Dlaczego on się tego bał? Bo był artykuł, proszę pana, którego nie objęła amnestia - chodziło o współpracę z Niemcami” ${ }^{47}$. O tym samym problemie wspominał zapewne w swoim zeznaniu Tadeusz Matraszek „Sokół”, jeden z byłych podkomendnych „Lalusia”. Wezwany 23 X 1963 r. przez funkcjonariuszy SB celem zidentyfikowania zwłok zabitego ostatniego partyzanta, po ich okazaniu został przesłuchany. Zeznając, poinformował, że on sam ujawnił się wiosna $1947 \mathrm{r}$. i do tego namawiał również swojego dowódcę. Ten miał mu odpowiedzieć, że tego nie zrobi, gdyż „[...] się boi ujawnić, gdyż w okresie okupacji łapał i strzelał Żydów"48.

Franczak poważnie rozważał możliwość ujawnienia się. Jednemu ze swoich współpracowników miał powiedzieć, że gdyby dostał gwarancję, że po wyjściu z podziemia otrzyma wyrok niższy niż 15 lat, to by z amnestii skorzystał. Prawdopodobnie wiosna 1956 r. spotkał się konspiracyjnie z Ryszardem Rachwaldem, jednym z lubelskich adwokatów, chcąc się go poradzić w tej kwestii. Nie znamy dokładnej treści ich rozmowy. Prawnik miał wyrazić opinię, że Franczakowi groziła kara dożywotniego więzienia. Nie wiemy, w oparciu o jaki zasób wiedzy porada ta została udzielona. Zapewne posiłkując się radami mecenasa, Franczak nie zdecydował się ostatecznie na ujawnienie ${ }^{49}$.

$$
* * *
$$

W trakcie ukrywania poszukiwani byli zmuszeni do przezwyciężania niesamowitych trudności. Począwszy od zapewnienia sobie kwatery (czasami jakiegokolwiek miejsca do spania), codziennego pożywienia, odzieży, czystej bielizny na zmianę czy niekiedy koniecznej opieki lekarskiej. Przebywali w przeróżnych miejscach, latem najczęściej w lesie, kamieniołomach. Najtrudniej przetrwać było zimą. Niektórym udało się wyszukać gospodarza, który godził się użyczyć kwatery przez dłuższy czas. Z relacji Kiszki wynika, że kilka kolejnych zim spędzał w podziemnym bunkrze wykopanym w lesie w okolicach Huty Krzeszowskiej w powiecie biłgorajskim. Gromadził w nim zapasy żywnościowe pozwalające przetrwać mu w bunkrze przez kilka miesięcy ${ }^{50}$. W ziemiankach wykopanych w lesie w okolicy wsi Korwki i Siwki

${ }^{47}$ Rozmowa Stanisława Kuźnika z Wacławem Szaconiem z 20 IV 2008 r., kopia w zbiorach autora. Ponadto dodał jeszcze: „[...] Po swoim siedzeniu byłem zorientowany w artykułach [Szacoń opuścił więzienie w grudniu 1956 r. - S.P.]. Był taki okres, kiedy Żydzi stanieli i ja mu powiedziałem, że dostanie najwyżej siedem, osiem lat. Ale Józek i tak się bał. Powiedział: «Moga mi dać osiem lat, ale mogą mnie i tak wykończyć»". Ibidem.

${ }^{48}$ S. Poleszak, Czy okupacyjna przeszłość..., s. 273-274.

${ }^{49}$ Idem, Kryptonim „Pożar”. Rozpracowanie i likwidacja ostatniego żotnierza polskiego podziemia niepodlegtościowego Józefa Franczaka „Lalka”, „Lalusia” (1956-1963), „Pamięć i Sprawiedliwość" 2005, nr 2 (8), s. 348-349.

${ }^{50}$ Relacja Andrzeja Kiszki z 12 X 2009 r., w zbiorach autora; B. Ilcewicz, Żotnierz nadal Wyklęty. Kpt. Andrzej Kiszka „Dqb”, „Wyklęci” 2016, nr 2, s. 68-69. 
na Kurpiach ukrywał się również Korwek. Z kolei grupa „Ryby” od jesieni 1953 r. do marca 1957 r. większość czasu spędzała w podziemnym bunkrze pod chlewem w zabudowaniach Apolinarego Grabowskiego w Kolonii Jeziorko k. Łomży. Gospodarstwo położone na uboczu gwarantowało względne bezpieczeństwo. Bunkry Kiszki i grupy „Ryby” były doskonale zamaskowane, a wyposażenie pozwalało na wegetację. Szczególne trudności z ukrywaniem się miał Dołęga, który w wyniku nieostrożnego obchodzenia się z bronią postrzelił się $\mathrm{w}$ obie nogi. Pomimo operacji $\mathrm{w}$ następnych latach problemy z poruszaniem się narastały. Nieunikniona okazała się amputacja jednej z kończyn. Przez pewien czas poruszanie się umożliwiała mu prowizoryczna proteza. W ostatnich latach życia nie mógł chodzić o własnych siłach i trzeba było przenosić go ${ }^{51}$.

$\mathrm{Na}$ stan psychiczny ukrywajacych się wpływ miały zapewne ich relacje z najbliższymi. Wacław Dąbrowski, gdy zaczął się ukrywać w 1949 r., $\mathrm{w}$ domu pozostawił niedawno poślubioną żonę, która wobec zaistniałej sytuacji musiała sama prowadzić kilkunastohektarowe gospodarstwo rolne. W świetle prawa cywilnego nie byli małżeństwem, mając jedynie ślub kościelny. Z kolei w grudniu 1952 r. Józef Cieśla zawarł ślub kościelny z Heleną Piękoś. W kwietniu 1954 r. urodził im się syn, a we wrześniu 1955 r. - córka. Ślub cywilny z Danuta Mazur chciał zawrzeć Józef Franczak, ale spotykali się z odmową księży, którzy zapewne czynili to w obawie przed konsekwencjami. W styczniu 1958 r. urodził się im syn Marek. Te fakty zapewne wpłynęły na przemyślenia niektórych o potrzebie wyrwania się z matni.

Warto pamiętać, że członkowie rodzin i krewni byli poddawani szczególnie silnej inwigilacji ze strony UB/SB. Częste nachodzenie, wezwania na przesłuchania, zastraszanie, rewizje (niejednokrotnie połączone z rabunkiem, szczególnie w latach czterdziestych i na początku lat pięćdziesiątych), niszczenie dobytku, bezwzględne egzekwowanie obowiązkowych dostaw produktów rolnych (nakładanie wysokich kar finansowych w wypadku niewywiązywania się $\mathrm{z}$ tego przymusu), zakładanie aparatury podsłuchowej czy werbowanie do tajnej współpracy. Zdarzały się też przypadki aresztowań. Oprócz wspomnianego wcześniej uwięzienia Heleny Piękoś, na początku 1956 r. kilka miesięcy w areszcie spędziła Jadwiga Dabrowska.

Należy podkreślić, że po kwietniu $1956 \mathrm{r}$. żaden z nich nie prowadził już działalności antykomunistycznej. Aktywność niektórych ograniczała się jedynie do drobnych akcji rabunkowych, aby pozyskać środki potrzebne podczas ukrywania się, np. Kiszka dokonał zaboru nieużywanej szafy drewnianej, która wykorzystał do zbudowania podziemnego bunkra. Ponadto Franczak w styczniu 1959 r. postrzelił w lesie, będącego w nim nieprzypadkowo, milicjanta z KW MO w Lublinie ${ }^{52}$.

${ }^{51}$ J. Karczewski, R. Werelich, op. cit., s. 110.

${ }^{52}$ S. Poleszak, Kryptonim „Pożar”..., s. 349. 
Wobec tych, którzy nie skorzystali z amnestii, funkcjonariusze SB prowadzili działania operacyjne majace na celu skłonienie ich do ujawnienia się. W trakcie obowiązywania amnestii funkcjonariusze SB osobiście bądź za pośrednictwem tajnych współpracowników próbowali oddziaływać na krewnych ukrywających się, aby ci wywarli na nich wpływ i skłonili ich do ujawnienia się (Franczak, Kiszka, Wysocki, Dąbrowski). Niepowodzenie tych zabiegów powodowało, że głównym celem SB stawało się zlokalizowanie ich miejsca pobytu, a następnie ujęcie lub zabicie. Używano szerokiego wachlarza narzędzi. Najpowszechniejszy sposób pozyskiwania wiadomości stanowiła tajna współpraca z posiadaną siecią informacyjna, którą w ramach operacji przeciwko danej osobie ciagle rozbudowywano, np. w przypadku Franczaka było to nawet kilkadziesiąt osób. Inwigilacji poddawano przede wszystkim członków rodziny, znajomych, dawnych towarzyszy z konspiracji, sąsiadów itd. Najszybszy efekt działania te przyniosły w odniesieniu do grupy Marchewki „Ryby”. Funkcjonariuszom SB udało się skłonić do współpracy siostrę Wysockiego, której nadano kryptonim „Zdzisława”. Otrzymawszy gwarancje, że w przypadku ujawnienia przez brata miejsca usytuowania bunkra nie poniesie on żadnej odpowiedzialności karnej, zgodziła się na skłonienie go do podjęcia takiej decyzji. Późniejsze zapewnienie go o tym, że odpowiedzialnościa nie zostanie obarczony również Dąbrowski, przekonało go do zdradzenia miejsca ich pobytu. Z 3 na 4 III 1957 r. grupa operacyjna SB-KBW, licząca 60 żołnierzy, otoczyła zabudowania Grabowskiego. Działania podjęto, gdy w bunkrze znajdował się tylko Marchewka. Został on zastrzelony przez funkcjonariuszy SB. Jego zwłoki przez kilka dni leżały na podwórku siedziby Komendy Powiatowej MO w Łomży. Następnie zostały wydane rodzinie i pochowane na cmentarzu parafialnym w Piątnicy. Dąbrowski i Wysocki ujawnili się formalnie w Prokuraturze Wojewódzkiej w Białymstoku. Wysocki uczynił to 8 marca, a Dąbrowski - 18 marca. Dąbrowski zdał automat, pistolet maszynowy, kilkadziesiąt sztuk amunicji i dwa granaty. Obaj po złożeniu obszernych wyjaśnień zostali zwolnieni ${ }^{53}$. Wysocki zmarł we wrześniu 1984 r., a Dąbrowski - w marcu 2015 r.

Funkcjonariusze SB podobny efekt osiagnęli w stosunku do Romualda Korwka, choć działania trwały zdecydowanie dłużej. Pomimo że śledztwo $\mathrm{w}$ jego sprawie zostało umorzone na podstawie amnestii z kwietnia $1956 \mathrm{r}$., a on wiedział o tym już od 1957 r., nie chciał wyjść z ukrycia. Funkcjonariusze SB przez długi czas nakłaniali go do tego za pośrednictwem jego krewnych. Dopiero po otrzymaniu gwarancji, że nie spotkaja go żadne sankcje prawne, w 1961 r. zgłosił się do Prokuratury Wojewódzkiej w Białymstoku. Miał wtedy

${ }^{53}$ Idem, Jeden $z$ wyklętych..., s. 284-286; K. Sychowicz, op. cit., s. 31-33; AIPN, 0156/1/5, Akta grupowego rozpracowania agenturalnego kryptonim „Biebrza” dotyczące Stanisława Marchewki „Ryby”, Streszczenie materiałów w sprawie przeciwko Tadeuszowi Wysockiemu i Wacławowi Dąbrowskiemu, Białystok, 16 IX 1957 r., k. 322. 
61 lat. Przez następne lata mieszkał w Dębnikach k. Zbójnej, gdzie pomagał swojej bratanicy w prowadzeniu gospodarstwa rolnego. Zmarł $4 \mathrm{~V} 1982 \mathrm{r.}^{54}$

Zupełnie inaczej wyglądało to w trzech innych przypadkach (Krupa, Kiszka, Franczak). Aby ich osaczyć, funkcjonariusze SB potrzebowali zdecydowanie dłuższego czasu. 11 II 1959 r. w zabudowaniach Dymitra Cala, we wsi Kulno w powiecie leżajskim, przez grupę operacyjną SB-ZOMO został otoczony Michał Krupa. Informację o jego pobycie denuncjator przekazał SB telefonicznie. Krupa poddał się, nie chcąc narażać domowników, w tym małych dzieci. 30 XI 1959 r. Sąd Wojewódzki w Rzeszowie na sesji wyjazdowej w Przemyślu skazał go na karę dożywotniego więzienia. Po zastosowaniu przepisów amnestii z $1956 \mathrm{r}$. karę zmniejszono do 15 lat więzienia, a po rewizji wyroku - do 8 lat. Mury więzienia opuścił w czerwcu 1965 r. Osiadł $\mathrm{w}$ Ulanowie w powiecie niżańskim, gdzie mieszkała jego siostra z rodzina. Rok po odzyskaniu wolności zawarł związek małżeński. Wieloletnie ukrywanie się i ciężkie warunki życia więziennego zrujnowały jego zdrowie. Zmarł 24 VIII 1972 r. $^{55}$

Dwa ostatnie przypadki są dowodem na to, że o sukcesie SB zadecydowały wytrwała i konsekwentna praca operacyjna oraz pozyskanie do współpracy osób, które wprowadzone w długotrwała grę operacyjna, w jej finale doprowadziły SB do poszukiwanego. W przypadku Andrzeja Kiszki taki zabieg polegał na wytypowaniu i osaczeniu, a następnie zmuszeniu do tajnej współpracy informatora „Klona” (lipiec 1960 r.). Był nim Bronisław Szpyt, kuzyn i jeden z najbliższych pomocników Kiszki ${ }^{56}$. Szpytowi udawało się lawirować prawie przez półtora roku, ale naciskany przez esbeków podał miejsce usytuowania bunkra. 30 XII 1961 r. sześćdziesięcioosobowa grupa operacyjna SB-ZOMO, wraz z agentem, którego przebrano w mundur milicjanta, przez kilka godzin przeszukiwała masyw leśny koło Huty Krzeszowskiej. Pomimo pomysłowego zamaskowania włazu do bunkra, został on odnaleziony, po czym ze środka wyszedł całkowicie zaskoczony Kiszka. Po półrocznym śledztwie 25 VII 1962 r. Sąd Wojewódzki w Lublinie skazał go na karę dożywotniego więzienia, obniżoną później do 15 lat pozbawienia wolności. W lipcu 1969 r. podczas pobytu w Ośrodku Pracy dla Więźniów w Strzelcach Opolskich wraz z innymi więźniami wystapił z protestem przeciwko zbyt niskiemu obniżeniu kar dla więźniów na podstawie amnestii z okazji dwudziestopięciolecia PRL. Został za to ukarany trzydziestodniowym twardym łożem. W sierpniu 1971 r. odzyskał wolność na zasadzie warunkowego zwolnienia. Osiadł na terenie powiatu łobeskiego w województwie szczecińskim. W marcu $1972 \mathrm{r}$. ożenił się z wdową po swoim młodszym bracie Józefie, który zmarł w wieku

${ }_{54}$ J. Karczewski, op. cit., s. 62.

${ }_{55}$ A. Szycht, Michat Krupa „Wierzba”..., s. 58, 66-67; D. Garbacz, Ostatni partyzant..., s. 41-43.

56 AIPN Lu, 00103/203, Teczka personalna t.w. „Klon” t. 1; ibidem, Teczka pracy t.w. „Klon”, t. 2. 
36 lat i osierocił dwójkę małych dzieci. Pod koniec lat dziewięćdziesiątych XX w. Sąd Wojewódzki w Lublinie tylko częściowo unieważnił wyrok z 25 VII 1962 r. ${ }^{57} \mathrm{~W}$ pełni uczynił to dopiero 27 XI 2018 r. Sąd Apelacyjny w Lublinie ${ }^{58}$. Kiszka zmarł 14 VI 2017 r. Został pochowany na cmentarzu parafialnym w Rogowie w powiecie łobeskim w województwie zachodniopomorskim.

Niemal dwa lata dłużej wytrwał Józef Franczak „Laluś”. Wynikało to głównie z dwóch czynników: zbudowania siatki ostrzegawczo-aprowizacyjno-kwaterunkowej liczacej według szacunków UB/SB ponad 200 osób oraz - co przyznawali w dokumentacji sami funkcjonariusze SB - rozpoznania niektórych metod stosowanych wobec niego przez policję polityczna. Podobnie jak w przypadku ujęcia Kiszki, przełomem okazały się wytypowanie, zwerbowanie (maj 1963 r.), a następnie umiejętne wykorzystywanie możliwości TW „Michała”. Chodzi o Stanisława Mazura, który był bratem stryjecznym Danuty Mazur, narzeczonej Franczaka i matki jego syna. Kiedy w sierpniu 1963 r. „Michałowi” udało się spotkać z „Lalusiem”, esbecy mieli pewność, że osoba agenta stwarza możliwość do ostatecznego rozwiązania sprawy ściganego. W przeddzień finału operacji „Michał” przekazał dane, które umożliwiły ustalenie miejsca pobytu poszukiwanego. 21 X 1963 r. ponad trzydziestoosobowa grupa SB i ZOMO zaskoczyła go w zabudowaniach Wacława Becia we wsi Majdan Kozic Górnych w powiecie lubelskim. Prowadząc ogień z posiadanych pistoletów, próbował wyrwać się z okrążenia. Został trafiony serią $\mathrm{z}$ automatu, w wyniku czego zmarł ${ }^{59}$. Prokurator powiatowy w Lublinie zarządził sekcję zwłok, w trakcie której odjęto, a następnie wymacerowano czaszkę denata. Zwłoki pochowano w bezimiennej mogile na cmentarzu przy ul. Unickiej w Lublinie. Informacja o tym dotarła do rodziny. Po 1 XI 1963 r. jego siostry wraz z grabarzem rozkopały mogiłę. Na podstawie charakterystycznego znamienia na nodze rozpoznały zwłoki brata. Był pochowany w trumnie, nagi, bez głowy. W 1983 r. siostry ponownie wydobyły szczątki, które złożono w grobowcu rodzinnym na cmentarzu parafialnym w Piaskach ${ }^{60}$. Dopiero w grudniu 2014 r. w zasobach Uniwersytetu Medycznego w Lublinie udało się odnaleźć jego czaszkę. Po potwierdzeniu badań, 26 III 2015 r. czaszke pochowano w grobowcu w Piaskach ${ }^{61}$.

Zupełnie inaczej potoczyły się losy Dołęgi, który wytrwał w ukryciu przez następne 27 lat, aż do 1982 r. Przebywał u najbardziej zaufanych gospodarzy z terenu gmin Trzebieszów i Zbuczyn w powiecie łukowskim. Dla zmylenia UB/SB rozpuścił fałszywą informację, że pod przybranym nazwiskiem wyjechał

57 S. Poleszak, Andrzej Kiszka..., s. 41-43; B. Ilcewicz, op. cit., s. 68-70.

58 AIPN Lu, Ns 43/2018, Akta sprawy dotyczące unieważnienia wyroku Sądu Wojewódzkiego w Lublinie z dn. 25 VII 1962 w sprawie Andrzeja Kiszki, k. 4-20, 29-43.

59 S. Poleszak, Kryptonim „Pożar”..., s. 367 i n., 371-373.

${ }^{60}$ Idem, Ostatni leśny..., s. 93; J. Szcześniak, Józef Franczak „Lalek”, w: Ostatni komendanci..., s. 31.

${ }^{61}$ S. Poleszak, Ostatni leśny..., s. 94. 
na Ziemie Odzyskane. Aby ją uwiarygadniać przez kolejne lata za pośrednictwem swoich współpracowników z Częstochowy przesyłał kartki z pozdrowieniami. Docierały one na adresy współpracowników w okolicach Łukowa. Zmarł w wieku 68 lat, w 1982 r. (prawdopodobnie w lipcu lub sierpniu) na jednej z kwater we wsi Popławy-Rogale. Pochowano go w bezimiennej mogile w pobliskim lesie i spoczywał tam przez kolejne 35 lat. 13 VI 2017 r. mogiła została odnaleziona, a szczątki ekshumowane ${ }^{62}$. Po potwierdzeniu, że należały do Antoniego Dołęi, 19 XI 2017 r. złożono je na cmentarzu w Trzebieszowie.

$$
* * *
$$

Losy osób, które zdecydowały się zakończyć działalność podziemną w oparciu o amnestię uchwaloną 27 IV 1956 r. (Bolesław Ciborowski, Józef Jankowski, Kazimiera Krasowska, Aleksander Rusin, Zachariasz Tarnowski) czy też zostały „wyprowadzone z podziemia” w następnych latach (Wacław Dąbrowski, Romuald Korwek, Tadeusz Wysocki), świadczą o tym, że amnestia ta dla wielu osób stanowiła realną szansę powrotu do normalnego życia. Oczywiście wszyscy w mniejszym lub większym stopniu byli przez następne lata inwigilowani i kontrolowani przez SB. Jednak to nieporównywalnie niższa cena niż ta, którą zapłacili ci, którzy nie zdecydowali się na ten krok. Nie sposób odpowiedzieć na pytanie, jaki bieg przybrałyby zdarzenia, gdyby pięciu pozostałych (Antoni Dołęga, Józef Franczak, Andrzej Kiszka, Michał Krupa, Stanisław Marchewka) zgłosiło się do prokuratur, aby skorzystać z możliwości ujawnienia się. Wynika to również stąd, że wspomniana ustawa o amnestii nie zawierała jednoznacznych zapisów abolicyjnych. Każda z wymienionych osób była podejrzewana o popełnienie czynów, do których doszło $\mathrm{w}$ różnych okolicznościach. W każdym przypadku organa ścigania dysponowały zapewne różnym materiałem dowodowym. Dlatego też, gdyby ujawnili się, losy każdego z nich potoczyłyby się zapewne inaczej. Spośród pięciu wyżej wymienionych w najtrudniejszej sytuacji znajdowali się Józef Franczak i Stanisław Marchewka.

Z kolei pozostanie na tzw. stopie nielegalnej było skazaniem się na trwanie $\mathrm{w}$ beznadziejnym położeniu, któremu towarzyszyło wypatrywanie zmiany porządku światowego w przypadku wybuchu III wojny światowej bądź tė̇ oczekiwanie na przedawnienie się stawianych zarzutów. Lektura doniesień tajnych współpracowników czy relacje świadków wskazują na to, że wraz z pojawiającymi się informacjami o kolejnych kryzysach w polityce światowej (wydarzenia na Węgrzech, konflikt wokół Kanału Sueskiego czy kryzys w Zatoce Świń) odżywały nadzieje na zmianę tragicznego losu, niestety, tylko na krótko.

62 J. Karczewski, R. Werelich, op. cit., s. 110-113; J. Kopiński, Działalność grupy Romana Dawickiego („Lonta”) i Antoniego Dotegi („Znicz”), w: Ostatni leśni, red. T. Łabuszewski, Warszawa 2003, s. 108; J. Kopiński, Podziemie antykomunistyczne..., s. 53-55. 


\section{Streszczenie}

Artykuł szczegółowo przedstawia losy ośmiu ludzi, którzy nie skorzystali z amnestii w kwietniu 1956 r. i nadal ukrywali się z bronią w ręku przed komunistycznym aparatem represji. Wszyscy oni byli członkami polskiego podziemia niepodległościowego, działającymi w jego szeregach już za czasów okupacji niemieckiej. Kontynuowali walkę po wojnie, nie godząc się z objęciem przez komunistów władzy w Polsce. Wnikliwa analiza ich życiorysów pozwala poznać motywacje i przyczyny, które spowodowały, że nie skorzystali z możliwości ujawnienia się na podstawie amnestii z 27 IV $1956 \mathrm{r}$. Nie w każdym przypadku wpływ na tę decyzję miał nieprzejednany antykomunizm czy nieufność do komunistów, ale też inne uwarunkowania. Warto pamiętać, że niektórzy z nich ujawnili się na podstawie amnestii z 22 II 1947 r., jednak wskutek działań UB zostali ponownie „wepchnięci do lasu”. Lektura tekstu pozwala poznać charakter działalności, jaka prowadzili po kwietniu 1956 r. i odpowiedzieć na pytanie, czy była to aktywność o charakterze antykomunistycznym, czy raczej „przetrwaniowym”.

\section{The Last Eight Men: The Members of the Anti-Communist Underground Who Refused the Amnesty of 1956}

The article discusses the fate of eight men who refused to lay down their arms during the amnesty of 1956 and continued their fight against the communist regime. They joined the Polish underground resistance during the German occupation. After the war, they refused to accept the communist authorities in Poland. The analysis of their lives sheds light on their motives and reasons behind their refusal to accept the amnesty announced on 27 April 1956. Not all of those men were motivated by uncompromising anti-communism or mistrust towards the communists. It is worth remembering that some of them accepted the amnesty declared on 22 February 1947, yet the secret political police (UB) actions forced them back into hiding. The article addresses the question of whether their actions, conducted after April 1956, were motivated by their fierce anti-communism or by a simple will to survive.

\section{Bibliografia}

Bechta M., Muszyński W.J., Przeciwko Pax Sovietica. Narodowe Zjednoczenie Wojskowe $i$ struktury polityczne ruchu narodowego wobec reżimu komunistycznego 1944-1956, Warszawa 2017.

Broński Z. „Uskok”, Pamiętnik (wrzesień 1939 - maj 1949), red. S. Poleszak, wyd. 2 rozsz. i popr., Lublin-Warszawa 2015.

Chmielewska A., Drozdowska J., Gogolewska J., W godzinie próby. Żotnierze podziemia niepodległościowego $w$ Białostockiem po 1944 roku $i$ ich losy, wyd. 2 popr., BiałystokWarszawa 2018.

Chodakiewicz M.J., Żydzi i Polacy 1918-1955. Wspótistnienie - zagtada-komunizm, Warszawa 2002.

Dudek J., Amnestia jako środek walki aparatu bezpieczeństwa z podziemiem niepodległościowym na przyktadzie Lubelszczyzny, w: Komunistyczne amnestie lat 1945-1947 - drogi do „legalizacji” czy zagłady?, red. W.J. Muszyński, Warszawa 2012, s. 205-235.

Garbacz D., Ostatni partyzant „Wotyniaka”, „Wyklęci” 2016, nr 2, s. 36-43.

Garbacz D., Wotyniak, legenda prawdziwa, wyd. 3 popr. i rozsz., Stalowa Wola 2008.

Hanus W., Jeden z ostatnich. Stefan Kobos „Wrzos” (1900-1976). Przyczynek do dziejów konspiracji na Narolszczyźnie, Rzeszów 2019. 
Ilcewicz B., Żotnierz nadal Wyklęty. Kpt. Andrzej Kiszka „Dab”, „Wyklęci” 2016, nr 2, s. 64-71. Karczewski J., Niestusznie zapomniany. Romuald Korwek „Orzech” (1900-1961), „Wyklęci” 2016, nr 2, s. 58-63.

Karczewski J., Werelich R, Ostatni Żotnierz Wyklęty? Antoni Dotęga (1915-1982?), „Wyklęci” 2016, nr 2, s. 107-114.

Kersten K., Polacy. Żydzi. Komunizm. Anatomia pótprawd 1939-68, Warszawa 1992.

Kopiński J., Działalność grupy Romana Dawickiego (,Lonta”) i Antoniego Dołęi (,Znicz”), w: Ostatni leśni, red. T. Łabuszewski, Warszawa 2003, s. 92-108.

Kopiński J., Podziemie antykomunistyczne w powiecie tukowskim w latach 1944-1982. Zarys problematyki, Łuków 2018.

Mazur M., Antykomunistycznego podziemia portret zbiorowy 1945-1956. Aspekty mentalno-psychologiczne, Warszawa-Lublin 2019.

Niwiński P., Łabuszewski T., „Sprawa” Józefa Franczaka - czyli historia alternatywna ( $w$ zwiazku z praca Stawomira Poleszaka). Czy okupacyjna przeszłość sierż. Józefa Franczaka „Lalusia”, miała wptyw na powojenne losy „ostatniego zbrojnego”?, „Zagtada Żydów. Studia i materiaty”, nr 16, 2020, 233-277), „Pamięć i Sprawiedliwość” 2021, nr 1 (37), s. 649-703.

Paczkowski A., Żydzi w UB: próba weryfikacji stereotypu, w: Komunizm. Ideologia, system, ludzie, red. T. Szarota, Warszawa 2001, s. 192-204.

Pityński A., Mój wujek - niezłomny desperat. Por. Michał Krupa „Putkownik”, „Wierzba” (1920-1972), „Wyklęci” 2016, nr 2, s. 44-49.

Poleszak S., Andrzej Kiszka „Leszczyna”, Dab”, „Bogucki”, w: Ostatni komendanci. Ostatni żotnierze 1951-1963, red. M. Biernat i in., Warszawa 2016, s. 33-43.

Poleszak S., Czy okupacyjna przeszłość sierż. Józefa Franczaka „Lalusia” miała wpływ na powojenne losy „ostatniego zbrojnego”?, „Zagłada Żydów. Studia i Materiały” 2020, nr 16, s. $233-277$.

Poleszak S., Jeden z wyklętych Major Jan Tabortowski „Bruzda”, Warszawa 1998.

Poleszak S., Józef Franczak (1918-1963), w: Konspiracja i opór w Polsce 1944-1956. Stownik biograficzny, t. III, red. T. Balbus i in., Kraków-Warszawa-Wrocław 2007, s. 151-156.

Poleszak S., Kryptonim „Pożar”. Rozpracowanie i likwidacja ostatniego żotnierza polskiego podziemia niepodległościowego Józefa Franczaka „Lalka”, „Lalusia”(1956-1963), „Pamięć i Sprawiedliwość" 2005, nr 2 (8), s. 347-376.

Poleszak S., Ostatni leśny. Sierż. Józef Franczak „Laluś”, „Lalek”, (1918-1963), „Wyklęci” 2016, nr 2, s. 78-95.

Poleszak S., Podziemie antykomunistyczne w Eomżyńskiem i Grajewskiem (1944-1957), Warszawa 2004.

Poleszak S., Stanistaw Marchewka (1908-1957), w: Konspiracja i opór społeczny $w$ Polsce 1944-1956 Stownik biograficzny, t. I, red. J. Żaryn, J.T. Żurek, Kraków-WarszawaWrocław 2002, s. 275-277.

Puławski A., Postrzeganie żydowskich oddziałów partyzanckich przez Armię Krajowa i Delegature Rzqdu RP na Kraj, „Pamięć i Sprawiedliwość” 2003, nr 2 (4), s. 271-300.

Surdej M., Amnestie i akcja ujawnieniowa na Rzeszowszczyźnie w latach 1945-1956, w: Komunistyczne amnestie lat 1945-1947 - drogi do „legalizacji” czy zagłady, red. W.J. Muszyński, Warszawa 2013, s. 237-255.

Surdej M., Szufnarowa 25 lutego 1956 r., „Wyklęci” 2016, nr 2, s. 19-23.

Surdej M., „Trzy konspiracje”. Historia Aleksandra Rusina ps. „Rusal”, Rzeszów-Warszawa 2020.

Sychowicz K., Nie poddat się do końca. Stanistaw Marchewka „Ryba”(1908-1957), „Wyklęci” 2016, nr 2, s. 25-35.

Syrek W., Józef Cieśla „Topór”. Przeciw brunatnemu i czerwonemu zniewoleniu, Krosno 2009. 
Szcześniak J., Jan Tabortowski „Bruzda”, w: Ostatni komendanci. Ostatni żotnierze 1951-1963, red. M. Biernat i in., Warszawa 2016, s. 140-145.

Szcześniak J., Józef Franczak „Lalek”, w: Ostatni komendanci. Ostatni żotnierze 1951-1963, red. M. Biernat i in., Warszawa 2016, s. 18-31.

Szycht A., Józef Cieśla „Topór”, w: Ostatni komendanci. Ostatni żotnierze 1951-1963, red. M. Biernat i in., Warszawa 2016, s. 90-113.

Szycht A., Michat Krupa „Wierzba”, w: Ostatni komendanci. Ostatni żołnierze 1951-1963, red. M. Biernat i in., Warszawa 2016, s. 44-67.

Wołoszyn J., Stefan Kobos „Michorowski”, „Wrzos”, w: Ostatni komendanci. Ostatni żotnierze 1951-1963, red. M. Biernat i in., Warszawa 2016, s. 76-89.

Sławomir Poleszak - dr, historyk. Pracownik Oddziałowego Biura Badań Historycznych Instytutu Pamięci Narodowej w Lublinie; redaktor naczelny portalu www.ohistorie.eu. Zainteresowania badawcze dotyczą dziejów polskiego podziemia niepodległościowego (antykomunistycznego) po $1944 \mathrm{r}$. w Polsce oraz form jego zwalczania przez komunistyczny aparat represji. E-mail: slawomir.poleszak@ipn.gov.pl.

Slawomir Poleszak - PhD, historian, employee of the Historical Research Office of the Institute of National Remembrance, Branch in Lublin; editor-in-chief of the website www.ohistorie.eu. His research interests include the history of the Polish independence underground (anti-communist) after 1944 in Poland and the forms of fighting it by the communist repressive apparatus. E-mail: slawomir.poleszak@ipn.gov.pl. 